\title{
Angiotensin II type 1 receptor polymorphisms and susceptibility to hypertension: A HuGE review
}

Amy K. Mottl, MD, $M P H^{1}$, David A. Shoham, $P h D^{1,2,3}$, and Kari E. North, PhD ${ }^{2,4}$

\begin{abstract}
The angiotensin II type 1 receptor (AGTR1) plays an integral role in blood pressure control, and is implicated in the pathogenesis of hypertension. Polymorphisms within this gene have been extensively studied in association with hypertension; however, findings are conflicting. To clarify these data, we conducted a systematic review of association studies of AGTR1 polymorphisms and hypertension, and performed a meta-analysis of the rs5186 variant. Results show that the currently available literature is too heterogeneous to draw meaningful conclusions. The definition of hypertension and gender composition of individual studies helps to explain this heterogeneity. Although the structure and splicing pattern of AGTR1 would suggest a likely effect of polymorphisms within the promoter region on gene function, few studies have been conducted thus far. In conclusion, there is insufficient evidence that polymorphisms in the AGTR1 gene are risk factors for hypertension. However, most studies are inadequately powered, and larger well-designed studies of haplotypes are warranted. Genet Med 2008:10(8): 560-574.
\end{abstract}

Key Words: hypertension, renin-angiotensin system, receptor, angiotensin II type 1, polymorphism, association

\section{BACKGROUND}

\section{Gene}

The renin-angiotensin system (RAS) plays a fundamental role in blood pressure maintenance and is implicated as a likely etiologic factor in the development of hypertension. ${ }^{1}$ Angiotensin II is central to the pathway of the RAS, causing vasoconstriction, sodium, and water retention and is tightly intertwined with the cascade of inflammatory, thrombotic, and fibrotic factors. ${ }^{1,2}$ These effects are mediated directly and indirectly via two distinct receptors, angiotensin II receptor type 1 (AGTR1) and type 2 (AGTR2). ${ }^{2}$ The bulk of the literature supports AGTR1 as a likely culprit in pathologic states such as hypertension. In fact, angiotensin receptor blockers specific to AGTR1 are commonly prescribed antihypertensive medications which have also been shown to reduce the risk of other cardiovascular endpoints, independent of their antihypertensive effects. ${ }^{3,4}$ As such, the AGTR1 is an excellent candidate gene in the etiology of hypertension and other cardiovascular diseases (CVD).

From the ${ }^{1}$ Division of Nephrology and Hypertension, School of Medicine; ${ }^{2}$ Department of Epidemiology, School of Public Health, University of North Carolina, Chapel Hill, North Carolina; ${ }^{3}$ Department of Preventive Medicine and Epidemiology, Loyola University Chicago, Maywood, Illinois; and ${ }^{4}$ Carolina Center for Genome Sciences, University of North Carolina, Chapel Hill, North Carolina.

Amy K. Mottl, MD, UNC Kidney Center, CB\# 7155, 6008 Burnett Womack Building, Chapel Hill, NC 27599-7155.E-mail: amy_mottl@med.unc.edu.

Disclosure: The authors declare no conflict of interest.

Submitted for publication March 6, 2008.

Accepted for publication May 5, 2008

DOI: $10.1097 /$ GIM.0b013e3181809613
The AGTR1 gene is located on chromosome $3 \mathrm{q} 21-25$ and is more than $55 \mathrm{~Kb}$ long. ${ }^{5,6}$ Four transcription initiation sites have been described. ${ }^{5,7-9}$ AGTR1 is composed of five exons, with the first four encoding the $5^{\prime}$ untranslated region (UTR) and the fifth being the coding region. ${ }^{5}$ Five transcript variants have been reported. ${ }^{5}$ The abundance of variant 5 is negligible and some have discounted the existence of exon $4 .^{7}$ Exon 3 contains an ATG start site that is in-frame with the ATG start site of the open reading frame of exon 5 . Hence, transcript variant 3 and 4 wherein exon 5 is juxtaposed to exon 5 produces a receptor isoform with an additional 32 amino acids at the N-terminus. ${ }^{7}$ Its presence has been substantiated in vivo and seems to result in decreased affinity for angiotensin II. ${ }^{10}$ The five AGTR1 receptor variants also vary with respect to their relative tissue expression, with the heart and kidney mostly expressing variants 1 and $2 .{ }^{10}$

The single promoter in the $5^{\prime}$ region contains multiple regulatory sequences including several potential TATA boxes, two CAAT boxes, two overlapping SP1 recognition sequences, a GC box, and a cyclic-AMP-induced responsive element. ${ }^{5,9,11}$ Located in the $3^{\prime}$ region are two polyadenylation signals (AATAAA) and six nucleotide motifs in the $3^{\prime}$ region which correspond to an AUUUA sequence which may influence mRNA stability during posttranscriptional regulation. ${ }^{8}$

The AGTR1 product is found predominantly in vascular smooth muscle cells and the heart, adrenal gland, and kidney. ${ }^{2}$ The predominant short isoform is composed of 359 amino acids and has a molecular mass of $41.1 \mathrm{kDa} .{ }^{8}$ The longer isoform is composed of 391 amino acids and is an additional 3.8 $\mathrm{kDa}$ larger. ${ }^{7}$ It is a G-protein coupled receptor spanning seven transmembrane domains. ${ }^{8}$ The protein sequence of the gene product is well conserved. ${ }^{7}$ 


\section{Gene variants and frequency}

Search of NCBI db single nucleotide polymorphisms (SNPs) build 127 for SNPs of the AGTR1 gene validated by both frequency and cluster data yielded 278 entries with 15 being insertion/deletion polymorphisms and 262 SNPs. Located 213-214 base pairs upstream from exon 1 are two adjacent SNPs listed in $\mathrm{dbSNP}$ as a single insertion/deletion polymorphism (rs422858). ${ }^{9}$ Review of dbSNP submissions and population data demonstrate them to be SNPs in linkage disequilibrium (LD) as no evidence of a deletion could be found. For this polymorphism, we refer to the major allele as AG and the minor allele as CC. Four SNPs lie within the coding region, two of which are synonymous (rs5182 and rs5183) and two nonsynonymous polymorphisms. One nonsynonymous SNP (rs12721226) results in a change from alanine to threonine at amino acid position 163 and another (rs12721225) a change from alanine to serine at amino acid position 244 . The one polymorphism not documented in dbSNP is a CA dinucleotide repeat microsatellite polymorphism located in the $3^{\prime} \mathrm{UTR}$, which has a polymerase chain reaction product ranging between 128 and 146 basepairs. ${ }^{12,13}$

Online-only Tables 1A and 1B display allele and genotype frequencies of polymorphisms genotyped in populations of at least 100 apparently healthy, unrelated individuals from similar ancestry. For inclusion, studies had to be published in the English language and genotype distribution in Hardy-Weinburg Equilibrium. Several studies refer to the same polymorphism by different names depending on the method of nomenclature, reference sequence, and choice of initiation site. Hence, for the purpose of clarity polymorphisms will be referred to by their rs numbers. As recommended by the Human Genome Variation Society the precise location of each SNP is listed according to the reference genomic sequence (AF24599), and that referenced by the literature. ${ }^{14}$

The most well-studied AGTR1 SNP is rs5186 (also termed the A1166C variant) located in the 3' UTR. Although this SNP does not lie within a coding region or splice site, it has been hypothesized that it may affect mRNA stability and transcription, or alternatively be in LD with another polymorphism of regulatory significance. Frequencies of this variant range from $0.19-0.31$ in populations of European descent, ${ }^{15-22} 0.03-0.11$ in populations of Asian descent, ${ }^{23-27}$ and $0.05-0.08$ in studies of populations of African descent. ${ }^{28-33}$

Data on the function of AGTR1 polymorphisms is limited. One study utilized computational software to identify variations that have the potential to create and destroy transcription factor binding sites. ${ }^{34}$ The rs275652 SNP and the rs422858 polymorphisms may have such an effect; however, these need to be tested experimentally. Functional analysis of three nonsynonymous mutants have demonstrated altered binding affinities, cell surface expression and response to angiotensin II. ${ }^{35}$ Still, these mutants have yet to be confirmed by cluster or frequency data as they were induced experimentally. A haplotype within the promoter region, $\mathrm{T}(\mathrm{rs} 275651) \mathrm{T}(\mathrm{rs} 275652)$ AG(rs422858) A(rs275653), may have increased promoter activity in adrenal cortical and vascular smooth muscle cells. ${ }^{36} \mathrm{It}$ was proposed that this may be due to an increased binding of transcription factor C/EBP to the oligonucleotide containing the $\mathrm{A}(\mathrm{rs} 275653)$ variant. These data were presented in abstract form and complete publication including methods is awaited.

In vitro experiments of AUF1, an mRNA-binding protein, did not reveal any differences in binding capacity to the $3^{\prime}$ UTR between the $\mathrm{A}$ and $\mathrm{C}$ alleles of the rs 5186 polymorphism. ${ }^{37}$

Some have found an increase in mRNA levels associated with the $\mathrm{C}$ allele of rs5186. ${ }^{38} \mathrm{On}$ the contrary, Abdollahi et al. ${ }^{39}$ found rs5186 AGTR1 mRNA levels to be 0.8 -fold lower in heterozygotes than major allele homozygotes, and 0.27 -fold lower in minor allele homozygotes. Platelet AGTR1 binding sites do not vary by rs 5186 genotype. ${ }^{40}$

\section{Haplotypes}

Data from the International HapMap Project reveal three recombination hotspots within the AGTR1 gene. ${ }^{41}$ Caucasian populations yield two haplotype blocks; combined Japanese and Chinese populations three blocks; and African populations four haplotype blocks. Block one is the largest, spanning $16 \mathrm{~kb}$ and encompassing exon 2 and flanking intronic sequences. ${ }^{41}$ Block two is restricted to intron 2 as is the third block for African populations. Haplotype block three in Asian populations encompasses exon 3 and flanking intronic sequences. African populations possess a fourth haplotype block that is isolated to intron 3.

Antonellis et al. ${ }^{6}$ established a SNP map of the AGTR1 gene using a new protocol of long-range PCR and fragment cloning. ${ }^{6} \mathrm{LD}$ was greatest within $30 \mathrm{~kb}$ and $\mathrm{D}^{\prime}$ was at least 0.70 within $10 \mathrm{~kb}^{6}{ }^{6}$ Polymorphisms within the promoter region have exhibited extensive LD as have SNPs in exon five..$^{39,42-44}$ Additionally, LD has been demonstrated between rs5186 and SNPs within the coding region. ${ }^{39}$ Haplotype frequencies of the AGTR1 gene in populations $>100$ individuals of similar ancestry are illustrated in Table 1. For inclusion, variants had to be found within dbSNP build 127.

\section{Hypertension}

According to the $\mathrm{WHO}$, the current definition of hypertension is the persistent elevation of blood pressure above 140/90, while at rest, documented on at least three separate occasions. ${ }^{45}$ In diabetics, blood pressure above $130 / 80$ is defined as pathologic. ${ }^{45}$ There are multiple secondary causes of hypertension, including hyperaldosteronism, Cushing disease, and renal artery stenosis. ${ }^{46}$ Essential hypertension $(\mathrm{EH})$ is diagnosed when there is no obvious etiology. It is a complex, multifactorial polygenic disease, and is likely not one disease unto itself. Physiologic processes that contribute to the development of hypertension and may account for phenotypic variation include salt sensitivity, arterial compliance, vasoreactivity, and activity of the renin-angiotensin and adrenergic systems.

Hypertension is extremely common, occurring in $24 \%$ of all Americans and 28\% in the African American population. ${ }^{47}$ It was estimated in the year 2000 that more than one billion people have hypertension and this number may increase by an additional $4 \%$ by the year $2025 .{ }^{48}$ The highest prevalence of 
Table 1

Allele frequencies for CA repeat polymorphism within the $3^{\prime}$ UTR of the AGTR1 gene between positions 60117 and 60256 of genomic reference sequence AF24599

\begin{tabular}{lcc}
\hline & \multicolumn{2}{c}{ Allele frequencies } \\
\cline { 2 - 3 } Base pairs of allele & $\begin{array}{c}\text { French }(n=112), \\
\text { Davies }^{12}\end{array}$ & $\begin{array}{c}\text { Chinese }(n=145), \\
\text { Liu }^{13}\end{array}$ \\
\hline 128 & 0 & 0.02 \\
130 & 0 & 0.06 \\
132 & 0.02 & 0.01 \\
134 & 0.11 & 0.04 \\
136 & 0.09 & 0.14 \\
138 & 0.04 & 0.59 \\
140 & 0.46 & 0.07 \\
142 & 0.18 & 0.06 \\
144 & 0.10 & 0 \\
146 & 0.01 & 0 \\
\hline
\end{tabular}

hypertension is in established market economies, former socialist economies, and Latin American and Caribbean nations. ${ }^{48}$ Estimates in these regions range between 35 and $41 \%$ in men and $37-39 \%$ in women. The lowest prevalence of hypertension is in India and southeastern Pacific regions including Korea, Thailand, and Taiwan. ${ }^{48}$ These estimates are as low as $17-21 \%$ in men and $14-21 \%$ in women. In all regions, hypertension prevalence increases with age. Systolic blood pressure levels are higher, and hypertension more prevalent in men than women in younger age groups, whereas the reverse tends to be true in higher age groups across populations, suggesting a likely interaction between these two factors. ${ }^{48,49}$

Hypertension is an insidious disease, rarely resulting in acute symptoms. When left uncontrolled, however, it can lead to a multitude of CVD such as ischemic heart disease (IHD), stroke, congestive heart failure (CHF), and kidney disease. There is a log-linear relationship between blood pressure and relative risk of cardiovascular endpoints..$^{50}$ Worldwide, it is estimated that $49 \%$ of ischemic heart disease, $62 \%$ of stroke, $76 \%$ of a composite outcome of $\mathrm{EH}$, congestive heart failure, and kidney disease and $14 \%$ of other CVD (retinopathy, peripheral vascular disease) are attributable to a mean systolic blood pressure (SBP) $>115 \mathrm{~mm} \mathrm{Hg} .{ }^{51}$ In the year 2000 , approximately $12.8 \%$ of all deaths (7.1 million) and $4.4 \%$ of all disabilityadjusted life-years (64.3 million) were due to suboptimally controlled blood pressure. ${ }^{51}$ In the United States, it is estimated that as many as $50 \%$ of hypertensives are uncontrolled even when under the care of a physician. ${ }^{45}$ In some populations, especially African Americans, hypertension is difficult to control even with multiple antihypertensive medicines. ${ }^{52}$

Blood pressure levels and estimates of hypertension prevalence are highly variable even within regions of similar ethnic ancestry ${ }^{48,49}$ Historically, studies within the United States documented higher rates of hypertension in individuals of African descent than European descent, suggesting a genetic predisposition to hypertension..$^{47}$ Recent data, however, demonstrate similar hypertension prevalence between African Americans and Caucasian individuals residing in European nations. ${ }^{53}$ It has been suggested that environmental factors play at least as great a role in blood pressure variation as does genetics. ${ }^{49}$

Obesity, insulin resistance/diabetes and obstructive sleep apnea are tightly intertwined; however, each poses an independent risk factor for hypertension..$^{54-56}$ Obesity results in impaired natriuresis and glomerular hyperfiltration and resultant renal injury which then exacerbates sodium retention. ${ }^{54} \mathrm{Ob}$ structive sleep apnea has been found to have similar physiologic effects. ${ }^{57}$ Both obesity and insulin resistance lead to endothelial dysfunction via shared and unshared pathways that impact hormone, cytokine, and redox balance. ${ }^{58}$ Hyperglycemia in addition to insulin resistance promotes vascular changes and resultant hypertension via formation of advanced glycation endproducts, increased reactive oxygen species, and altered growth factor and cytokine production. ${ }^{59}$

The effect of salt intake on blood pressure variation across populations is well established. ${ }^{60,61} \mathrm{An}$ increase of $100 \mathrm{mmol} /$ day of salt intake has been estimated to account for a 3-6 mm $\mathrm{Hg}$ increase in systolic pressure and a $0-3 \mathrm{~mm} \mathrm{Hg}$ increase in diastolic blood pressure. ${ }^{62}$ Epidemiologic data suggest that at least in some populations, individuals with active lifestyles are less prone to hypertension. ${ }^{63,64} \mathrm{Alcohol}$ is also associated with hypertension, and the previous notion that moderate alcohol intake or specific forms of alcohol was cardioprotective has been dismissed. ${ }^{65}$ The negative effect of alcohol intake on blood pressure is dose-linear and seems to have a greater effect in men than women. ${ }^{66}$

Even when environmental factors are optimized, many continue to manifest with elevated blood pressures as a result of genetic predisposition. Hypertension has long been noted to exhibit familial clustering, with heritability estimates ranging between 30 and 50\%.67-70 The genetic basis of hypertension and current methodologic/epidemiologic roadblocks to its unraveling has been extensively reviewed. ${ }^{71,72}$ Both linkage and association studies of hypertension-related phenotypes have largely been disappointing with discrepant results due to a combination of insufficient power, poor phenotyping, population stratification, epistasis, and insufficient attention to gene-environment interactions. ${ }^{71}$

Genome-wide linkage studies have yielded largely divergent results with the exception of a quantitative trait locus for hypertension and/or blood pressure on 2p. ${ }^{73-76}$ Evidence does exist in support of an association between the endothelial nitric oxide synthase gene3 27 base-pair variable number tandem repeat polymorphism in intron $4(4 \mathrm{a} / \mathrm{b})$ and hypertension under a recessive model in Caucasian and Asian populations. ${ }^{77}$ Notably, findings were homogeneous even between studies of different ethnicity. Because of the major role of the RAS on blood pressure control, many of its components have been extensively studied with regard to hypertension. Results have been largely discrepant with respect to the angiotensionogen M235T, ${ }^{78,79}$ angiotensin converting enzyme (ACE) insertion/ 
deletion, ${ }^{79}$ and aldosterone synthase (CYP11B2) C-344T polymorphisms. ${ }^{80}$

\section{Objectives}

Numerous studies have been published associating polymorphisms of AGTR1 with hypertension, however results have been inconsistent. The purpose of this review is (1) to systematically present data relating AGTR1 gene polymorphisms in association with hypertension; and (2) to perform a meta-analysis of association studies of the rs5186 SNP and hypertension to both understand the relationship between this genetic variant and hypertension across multiple populations, and the apparent heterogeneity of findings inherent in the current literature.

\section{METHODS}

We searched PubMed (The National Library of Medicine) using the search terms "AGTR1 polymorphism" including dates 1966-March 2007. Additionally, the bibliographies of retrieved articles were reviewed for additional papers. Abstracts from the annual meetings of the American Heart Association and American Society of Hypertension were also searched for the years 1994-2006. The ISI Web of Science database was also searched for abstracts using the terms "AGTR1 Polymorphism Hypertension.” Inclusion criteria were: publication in the English language, either a case-control or casecohort study design, outcome of EH only, allele and/or genotype frequencies reported, stratification by ethnic background when more than one ethnic group was included and study participants at least 18 years of age (as the etiology of hypertension in children may be distinct from that in adults). Minor allele frequencies and genotype distributions were extracted from publications which focused on haplotype analysis, when possible. We additionally attempted to obtain genotype distributions of hypertensive and control groups in publications that restricted their analysis to minor allele frequencies.

For the rs5186 meta-analysis, the Stata Version 9.0 (StataCorp: College Station, TX) user-written program METAN (Bradburn, Deeks, and Altman) was used for analysis. We began by assessing whether there was heterogeneity within populations of similar ancestral descent. Some populations were difficult to classify, and hence were placed a priori into the population with the closest minor allele frequency. The DerSimonian and Laird random-effects model was employed to assess heterogeneity. ${ }^{81}$ The cut point for the $\chi^{2}$ test of heterogeneity from the Mantel-Haenszel model was set at $P<0.10$; this value was chosen because tests of heterogeneity are often underpowered. ${ }^{82} \mathrm{We}$ further assessed heterogeneity using the $\tau^{2}$ statistic (the variance between studies) and the $\mathrm{I}^{2}$ statistic (the proportion of total variance that is between studies); we interpreted at least $33 \%$ variance between studies as indicative of heterogeneity, precluding pooling of summary estimates across studies..$^{83}$ Because there were only two studies of populations of African ancestry, we did not assess heterogeneity within this stratum.
Heterogeneity between studies may be due to variability in study design characteristics or populations of study. For example, studies with older populations may show weaker associations between genotype and hypertension because competing risk factors predominate in older adults. Therefore, we undertook a meta-regression of available and relevant study features including: hypertension definition ("SBP $\geq 160 \mathrm{~mm} \mathrm{Hg}$ and/or on medication" vs. "SBP $\geq 140 \mathrm{~mm} \mathrm{Hg}$ and no mention of medication"), mean age of cases, \% male composition of cases, total cholesterol levels, and body mass index (BMI). Because of the limited number of studies conducted within Asian and African populations, meta-regression was conducted only within the European ancestry population. For predictors significant within the meta-regression $(P<0.10$, due to poor power using a small number of studies), stratified meta-analysis was performed with testing of between-study heterogeneity within each stratum. ${ }^{84}$ Additionally, multiple publications reported gender-specific data, and hence we ran stratified meta-analyses for these studies.

Because multiple and varying models of genetic effects for the hypertension phenotype have been assessed in the literature, we calculated odds ratios using multiple genetic models. For all polymorphisms the minor allele (a) versus the major allele (A), is considered the risk marker for hypertension. First, we calculated pairwise contrasts of the aa versus AA genotype and the Aa versus AA genotype ( $2 \mathrm{df}$ tests). Next, we employed an additive model, which assumes a monotonic increase in association with hypertension as one moves from zero to one and one to two copies of the minor allele. Finally, we calculated associations under an autosomal-dominant model (AD) that combines the aa and Aa genotypes in the numerator; and an autosomal-recessive model (AR) that combines the Aa and AA genotypes in the denominator. We attempted to infer the most likely model of inheritance by regressing the logodds-ratio of hypertension of the homozygous aa-versus-AA contrast (x-axis) against the heterozygous Aa-versus-AA contrast (y-axis), using results of each study. The slope of the regression parameter $(\lambda)$ will be zero under a perfectly AR model (only the aa genotype is associated with disease), one under a perfectly AD model (either one or two copies of the a allele confers risk of disease), and 0.5 under a codominant model..$^{85}$

Publication bias was assessed using Begg rank correlation test, Egger weighted regression test, and visual inspection of funnel plots of standard error of the log-odds-ratio against the log-odds-ratio. Egger test is considered the most sensitive of these tests, although funnel plots may reveal publication bias not detected by underpowered formal statistical tests. ${ }^{86}$

\section{RESULTS}

\section{Hypertension}

There were 38 studies (one studied two distinct populations) which satisfied inclusion criteria and analyzed the rs5186 AGTR1 polymorphism (Online-only Table 2) and eight which analyzed other SNPs in relation to hypertension categorized as a dichotomous variable (Table 2). Two studies were 


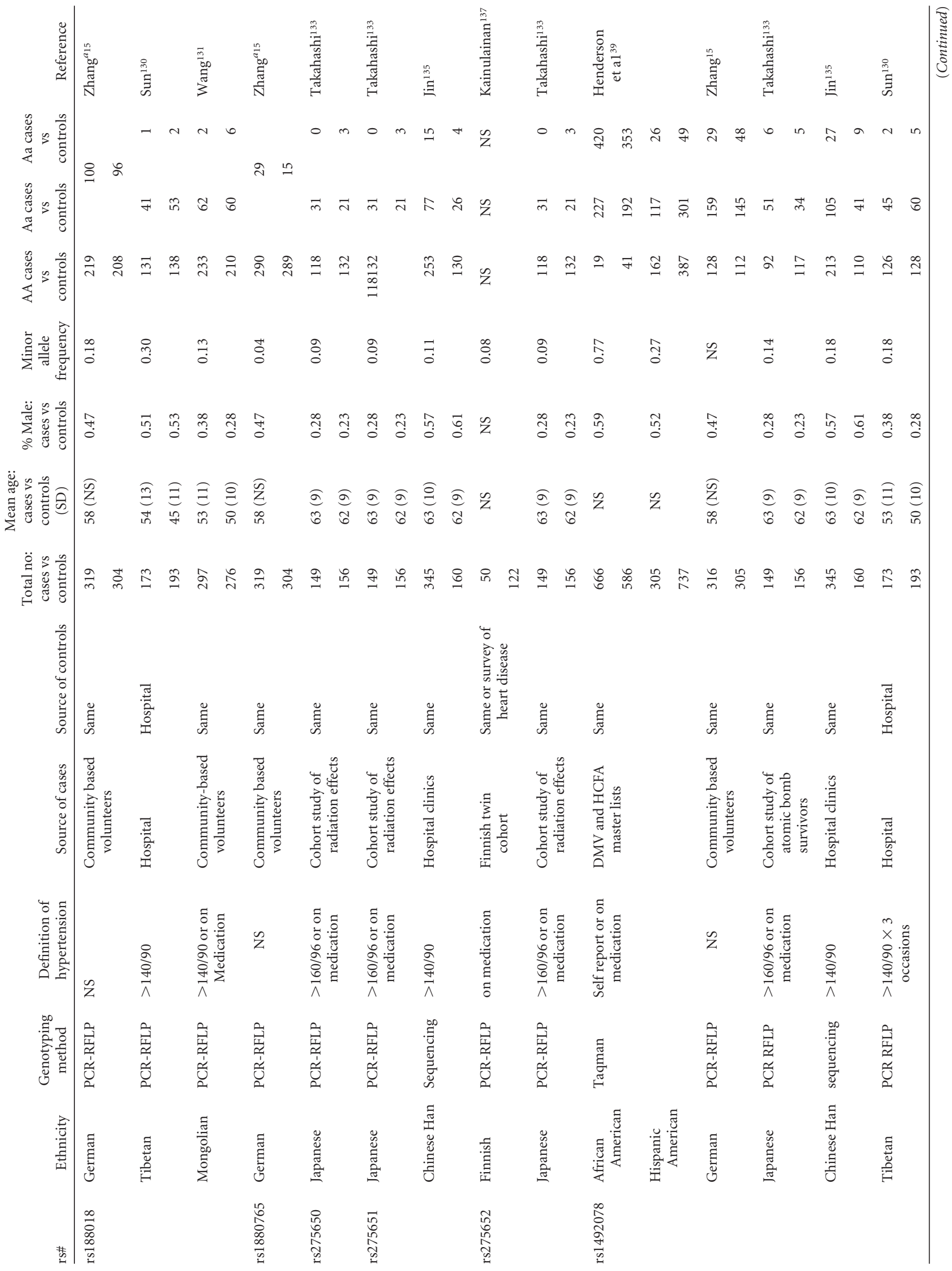




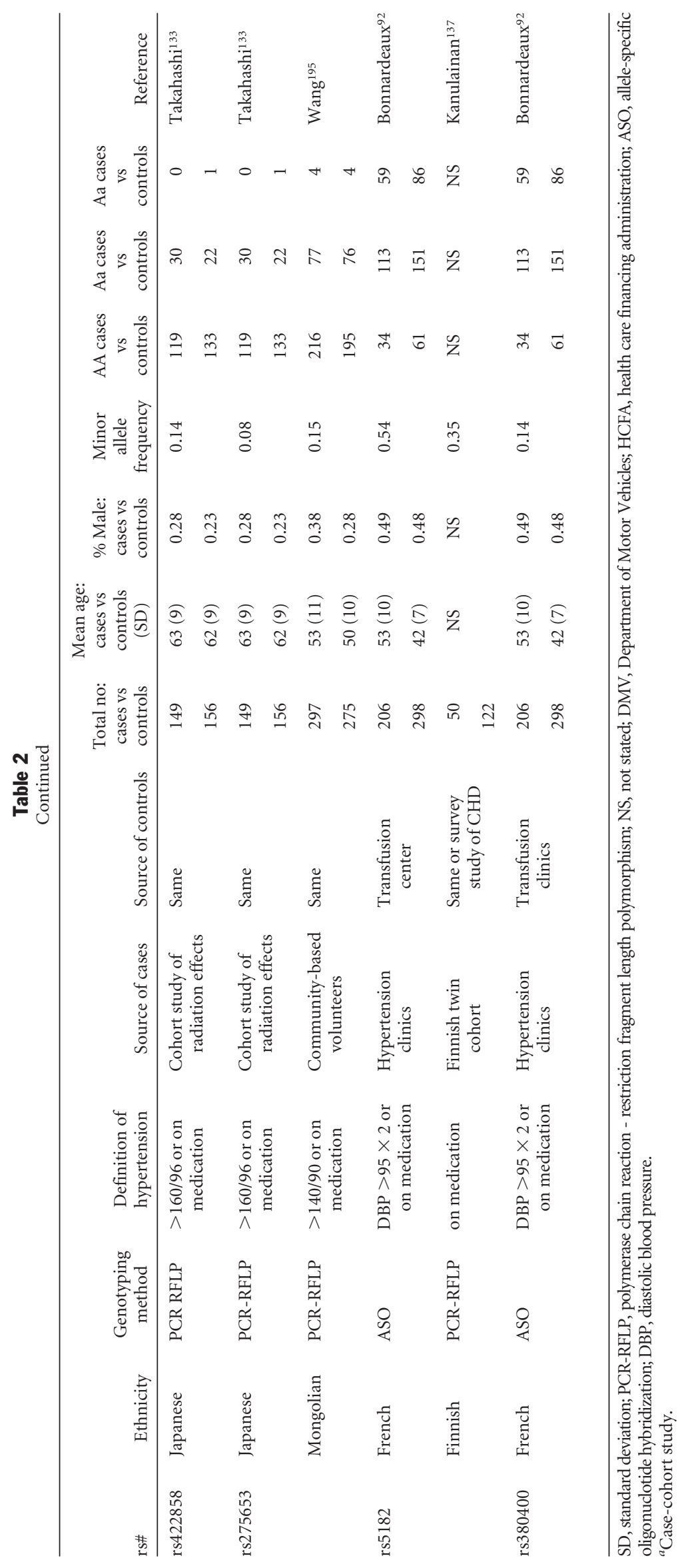


excluded due to analysis of redundant populations, ${ }^{87,88}$ one that did not genotype its own controls, ${ }^{89}$ and one because it did not clarify genotype categorization..$^{90}$ Two studies analyzed haplotypes of the AGTR1 gene, and risks for individual SNPs could not be extracted so these findings will be reported separately. ${ }^{36,91}$

Multiple methodological weaknesses were noted in the majority of studies listed in Tables 4 and 5. Sample sizes were small, definitions of hypertension were inconsistent between studies and sometimes inconsistent with currently accepted guidelines, classification of hypertension was based on a single point estimate, and often controls were sampled from different populations than cases. There was substantial variability in age, gender composition, cholesterol levels, and BMI both within and between studies.

Forest plots for association studies of rs5186 and hypertension status under dominant, recessive and additive genetic models are shown in Figure 1. Table 3 reports the tests of heterogeneity $\left(\chi^{2}, \tau^{2}\right.$, and $\left.\mathrm{I}^{2}\right)$, Egger publication bias test, and where appropriate, summary estimates (odds ratio (OR) and $95 \%$ confidence interval (CI)) of association studies of hypertension and rs5186 genotype under each genetic model. The heterogeneity $\chi^{2}$ and $\mathrm{I}^{2}$ tests led to identical conclusions. Pooled summary estimates are reported when studies may be regarded as nonheterogeneous $(P<0.10$ for the heterogeneity $\chi^{2}$ test, or $\left.\mathrm{I}^{2}<0.33\right)$. There was significant heterogeneity for both Asian and European populations under most genetic models. In searching for the most appropriate genetic model, results were difficult to interpret as we obtained slope values $>1.0$ for European populations and less than zero for Asian populations. These results may be related to the observed heterogeneity of studies.

None of the factors we examined explained the heterogeneity for the AR model using meta-regression. Under the $\mathrm{AD}$ model, the definition of hypertension and percent male composition of cases were significant predictors of heterogeneity $(P<0.10)$. For the studies that used "SBP $\geq 160 \mathrm{~mm} \mathrm{Hg}$ and/or on medication," odds ratios were $36 \%$ greater than studies with a definition of "SBP $\geq 140 \mathrm{~mm} \mathrm{Hg}$ and no mention of medication" (OR 1.36, 95\% CI 1.07-1.74). For the studies that were predominantly male, odds ratios were $60 \%$ lower than studies that were predominantly female (OR 0.40 , 95\% CI 0.20-0.82).

Next, we repeated the meta-analysis within strata identified by the meta-regression results. Strata were: definition of hypertension " $\geq 160 \mathrm{~mm} \mathrm{Hg}$ and/or on medication" versus " $\geq 140$ $\mathrm{mm} \mathrm{Hg}$ and no mention of medication" and male gender composition of cases $\geq$ or $<50 \%$ male. Results are given in Table 6 . There was no evidence of heterogeneity within studies stratified by these variables $(P>0.10)$. The test of heterogeneity is least powerful when looking within strata, and given there were as few as five studies within any stratum these results should be interpreted cautiously. Association of rs5186 genotype and hypertension was found using an $\mathrm{AD}$ model within studies that used a definition of hypertension $\geq 160 \mathrm{~mm} \mathrm{Hg}$ and/or on medication (D + L pooled OR 1.23, 95\% CI 1.06-1.43) and studies that were predominantly female $(\mathrm{D}+\mathrm{L}$ pooled $\mathrm{OR}$ $1.28,95 \%$ CI 1.10-1.48). Publication bias was evident in both strata (Egger $P<0.001$ and $P=0.003$, respectively). In assessing the most appropriate genetic model for analysis, results were difficult to interpret with a slope of $>2.0$ in the stratum using a definition of hypertension $\geq 160 \mathrm{~mm} \mathrm{Hg}$ and/or on medication and no correlation between the aa-versus-AA and Aa versus-AA contrasts in all other strata.

Study-level odds ratios for association of SNPs other than rs5186 with hypertension under $\mathrm{AD}, \mathrm{AR}$, and additive genetic models are provided in Table 4. Heterogeneity was assessed for SNPs with at least three studies including rs1492078 and rs188018 with $P$-values of $<0.10$ for all genetic models involving rs 1492078 and the AR model for rs188018. Results were nonheterogeneous for the AD model of rs188018 $(P=0.76)$, although there were a limited number of studies. The $\mathrm{D}+\mathrm{L}$ pooled OR was $0.91(95 \%$ CI 0.72-1.14), showing no association with hypertension. It should be noted that results for multiple SNPs were identical, given the presence of strong LD.

The AC repeat within the $3^{\prime}$ UTR was analyzed in two studies. One found an increased risk with the $140 \mathrm{bp}$ fragment in comparison with any other allele (OR 3.21, 95\% CI 1.28-8.04). ${ }^{13}$ The other examined allele frequencies between the case and control groups and found no difference, and did not report genotype frequencies to allow for additional analyses. ${ }^{92}$

Zhu et al. ${ }^{91}$ demonstrated a haplotype block containing the $\mathrm{C}$ allele from rs5182 and the $\mathrm{G}$ allele from rs5183 was possibly associated with hypertension in a case-control analysis of African Americans $(P<0.05)$. In this same study, using a haplotype transmission disequilibrium test in African American families, the CG haplotype was overtransmitted to hypertensive offspring $(P=$ 0.0002). No association was found in Caucasian Americans in this study ${ }^{91}$ Another study reported association of a haplotype block within the promoter region consisting of: $\mathrm{T}(\mathrm{rs} 275651)$ $\mathrm{T}(\mathrm{rs} 275652) \mathrm{AG}(\mathrm{rs} 422858) \mathrm{A}(\mathrm{rs} 275653)$, to be associated with hypertension but only in women. ${ }^{36}$ This haplotype reportedly also has functional significance as discussed earlier. Finally, although $\mathrm{Gu}$ et al. ${ }^{33}$ did not report genotype frequencies, it is worth mentioning due to its innovative approach which incorporated both additive and up to a four-way interactive effect. There were 503 stage two hypertensives and 490 age/gender-matched controls genotyped for $33 \mathrm{SNPs}$ located in 11 genes physiologically relevant to hypertension. AGTR1 SNPs rs275650, rs1492078, and rs5186 were not found to predict hypertension in a single locus analysis.

\section{Interactions}

\section{Epistasis}

Interaction between AGT M235T and AGTR1 rs5186 on both hypertension and blood pressure was investigated but no effect was demonstrated..$^{92,94,95}$ In studying interaction of the AGTR1 rs5186 with the angiotensin converting enzyme I/D polymorphism and hypertension, Ashavaid et al. ${ }^{97}$ found the $\mathrm{C}$ allele to be more frequent in hypertensive individuals with the $\mathrm{DD}$ genotype. Others have found no interaction between these two polymor- 
A

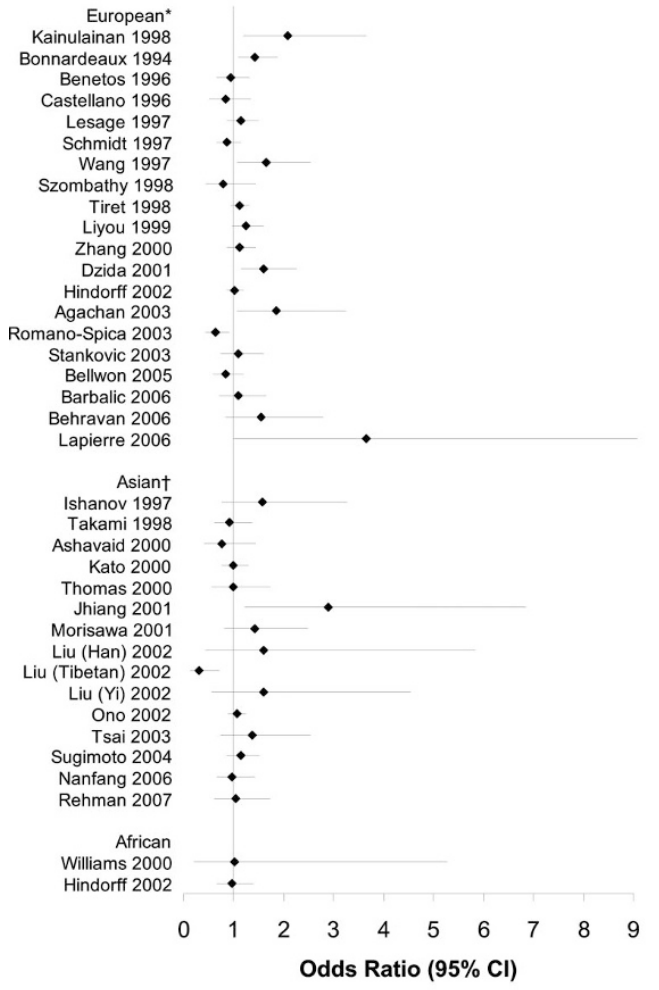

B

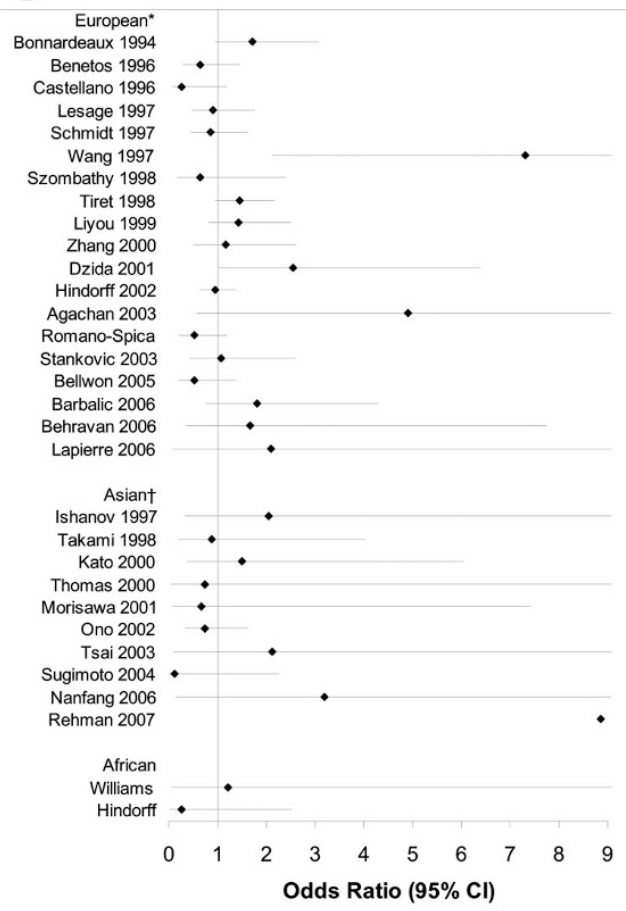

C

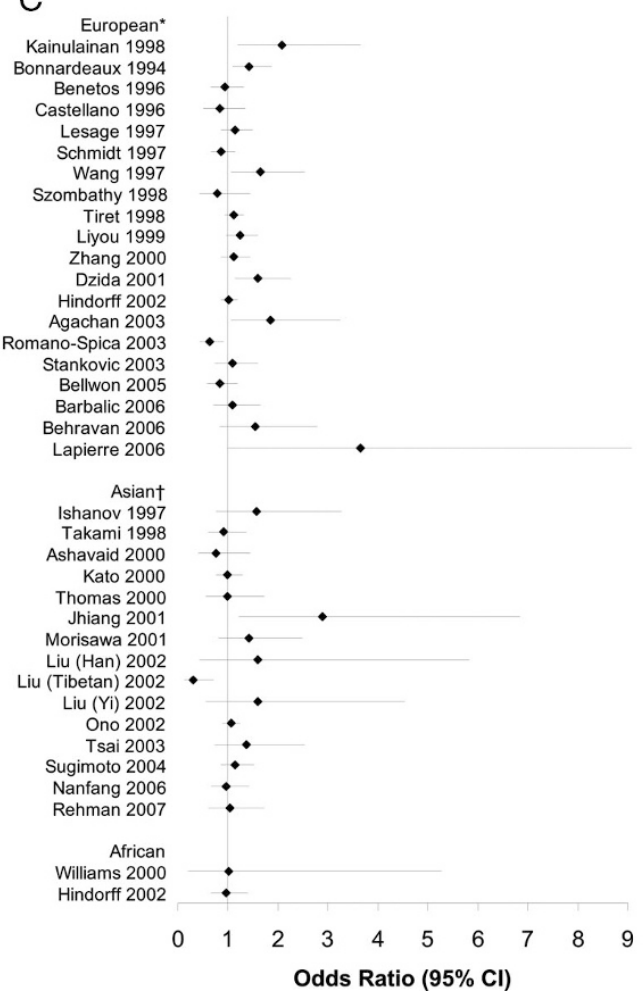

Fig. 1. A-C, Forest plots for dominant, recessive, and additive genetic models of rs5186 polymorphism in association with hypertension, including all studies. (Dotted line represents null value.) Filled $\mathrm{OR}$ is the adjusted estimate using meta-bias to estimate results if publication bias were not present. (1A) Dominant Model: ${ }^{\star}$ heterogeneity $\chi^{2} P=0.08 ; \tau^{2}=0.021 ; \mathrm{I}^{2}=$ $34 \%$; Egger's publication bias $P=0.51$. $\dagger$ Heterogeneity $\chi^{2} P=0.09 ; \tau^{2}=0.028 ; \mathrm{I}^{2}=35 \%$; Egger's publication bias $P=0.75$. (1B) Recessive Model: ${ }^{\star}$ heterogeneity $\chi^{2} P=0.08 ; \tau^{2}=0.074$ $\mathrm{I}^{2}=34 \%$; Egger's publication bias $P=0.98$. †Heterogeneity $\chi^{2} P=0.68 ; \tau^{2}=0.000 ; \mathrm{I}^{2}=0 \%$; Egger's publication bias $P=0.09$; Asian summary OR: 0.99 (95\%CI: 0.59, 1.68). (1C) Additive Model: ${ }^{*}$ heterogeneity $\chi^{2} P=0.001 ; \tau^{2}=0.040 ; \mathrm{I}^{2}=58 \%$; Egger's publication bias $P=0.47$. † Heterogeneity $\chi^{2} P=0.15 ; \tau^{2}=0.020 ; \mathrm{I}^{2}=28 \%$; Egger's publication bias $P=0.93$; Asian summary OR: $1.07(0.93,1.23)$. 
Mottl et al.

Table 3

Measures of heterogeneity of association ( $\chi^{2} p$-value, tau-squared, and I-squared), publication bias test, and summary estimates (odds ratio and $95 \%$ confidence intervals) of the angiotensin II Type 1 receptor gene A1166C(rs5186) single nucleotide polymorphisms and hypertension under dominant, recessive and additive genetic models for various subgroups

\begin{tabular}{|c|c|c|c|c|c|}
\hline Heterogeneity $\chi^{2} P$ & $\tau^{2}$ & $I^{2}$ & Egger's publication bias (\%) & Summary estimate & OR $(95 \% \mathrm{CI})$ \\
\hline \multicolumn{6}{|l|}{ European } \\
\hline $\mathrm{AD}$ & 0.08 & 0.021 & 34 & 0.51 & \\
\hline AR & 0.08 & 0.074 & 34 & 0.98 & \\
\hline Additive & 0.001 & 0.040 & 58 & 0.47 & \\
\hline \multicolumn{6}{|l|}{ Asian } \\
\hline $\mathrm{AD}$ & 0.09 & 0.028 & 35 & 0.75 & \\
\hline $\mathrm{AR}$ & 0.68 & 0.000 & 0 & 0.09 & $0.99(0.59-1.68)$ \\
\hline Additive & 0.15 & 0.020 & 28 & 0.93 & $1.07(0.93-1.23)$ \\
\hline \multicolumn{6}{|c|}{ Hypertension defined by blood pressure $\geq 160 / 95$ and/or use of antihypertensive medication } \\
\hline $\mathrm{AD}$ & 0.17 & 0.015 & 30 & 0.01 & $1.23(1.06-1.43)$ \\
\hline $\mathrm{AR}$ & 0.13 & 0.066 & 35 & 0.46 & \\
\hline Additive & 0.02 & 0.028 & 54 & 0.04 & \\
\hline \multicolumn{6}{|c|}{ Hypertension defined by blood pressure $\geq 140 / 90$, without mention of hypertensive medication } \\
\hline $\mathrm{AD}$ & 0.33 & 0.008 & 13 & 0.62 & $0.90(0.74-1.10)$ \\
\hline $\mathrm{AR}$ & 0.01 & 0.399 & 68 & 0.28 & \\
\hline Additive & 0.03 & 0.051 & 60 & 0.36 & \\
\hline \multicolumn{6}{|l|}{ Cases mostly men } \\
\hline $\mathrm{AD}$ & 0.85 & 0.000 & 0 & 0.48 & $1.02(0.87-1.20)$ \\
\hline $\mathrm{AR}$ & 0.08 & 0.186 & 47 & 0.10 & \\
\hline Additive & 0.48 & 0.000 & 0 & 0.13 & $1.03(0.91-1.16)$ \\
\hline \multicolumn{6}{|l|}{ Cases mostly women } \\
\hline $\mathrm{AD}$ & 0.28 & 0.009 & 18 & 0.01 & $1.28(1.10-1.48)$ \\
\hline $\mathrm{AR}$ & 0.04 & 0.164 & 51 & 0.05 & \\
\hline Additive & 0.04 & 0.026 & 50 & 0.01 & \\
\hline \multicolumn{6}{|l|}{ European men } \\
\hline $\mathrm{AD}$ & 0.13 & 0.075 & 39 & 0.34 & \\
\hline AR & 0.26 & 0.112 & 23 & 0.39 & $0.93(0.53-1.63)$ \\
\hline Additive & 0.09 & 0.063 & 45 & 0.82 & \\
\hline \multicolumn{6}{|l|}{ European women } \\
\hline $\mathrm{AD}$ & 0.24 & 0.053 & 25 & 0.93 & $1.36(0.97-1.92)$ \\
\hline $\mathrm{AR}$ & 0.62 & 0.000 & 0 & 0.35 & $1.65(0.96-2.86)$ \\
\hline Additive & 0.24 & 0.070 & 40 & 0.72 & \\
\hline \multicolumn{6}{|l|}{ Asian men } \\
\hline $\mathrm{AD}$ & 0.03 & 0.149 & 64 & 0.18 & \\
\hline AR & 0.71 & 0.000 & 0 & 0.08 & $0.97(0.35-2.66)$ \\
\hline Additive & 0.04 & 0.120 & 61 & 0.31 & \\
\hline \multicolumn{6}{|l|}{ Asian women } \\
\hline $\mathrm{AD}$ & 0.04 & 0.150 & 61 & 0.47 & \\
\hline $\mathrm{AR}$ & 0.99 & 0.000 & 0 & 0.34 & $0.70(0.30-1.65)$ \\
\hline Additive & 0.06 & 0.104 & 56 & 0.45 & \\
\hline
\end{tabular}


Table 4

Odds ratios and 95\% confidence intervals for association of angiotensin II type 1 receptor single nucleotide polymorphisms and hypertension under dominant, recessive and additive genetic models

\begin{tabular}{|c|c|c|c|c|c|c|c|c|}
\hline \multirow[b]{2}{*}{ rs\# } & \multirow[b]{2}{*}{ Ethnicity } & \multirow[b]{2}{*}{ Reference } & \multicolumn{2}{|c|}{ Autosomal dominant } & \multicolumn{2}{|c|}{ Autosomal recessive } & \multicolumn{2}{|c|}{ Additive } \\
\hline & & & OR & $95 \% \mathrm{CI}$ & OR & $95 \% \mathrm{CI}$ & OR & $95 \% \mathrm{CI}$ \\
\hline \multirow[t]{5}{*}{ rs188018 } & German & Zhang 2000 & 0.99 & $(0.71-1.39)$ & & & 0.99 & $(0.95-1.04)$ \\
\hline & Tibetan & Sun 2004 & 0.80 & $(0.5-1.28)$ & 0.56 & $(0.35-0.89)$ & 0.82 & $(0.75-0.9)$ \\
\hline & Mongolian & Wang 2006 & 0.87 & $(0.59-1.29)$ & 0.31 & $(0.21-0.45)$ & 0.83 & $(0.78-0.89)$ \\
\hline & & Summary & $0.91^{\mathrm{a}}$ & $0.72-1.13$ & & & $0.90^{b}$ & $0.73-1.10$ \\
\hline & & \multicolumn{3}{|c|}{$I^{2}=0 \%$} & & & \multicolumn{2}{|c|}{$I^{2}=0 \%$} \\
\hline rs1880765 & German & Zhang 2000 & 1.93 & $(1.01-3.67)$ & & & 1.88 & $(1.53-2.31)$ \\
\hline rs275650 & Japanese & Takahashi 2000 & 1.44 & $(0.8-2.6)$ & & & 1.23 & $(1.05-1.42)$ \\
\hline \multirow[t]{2}{*}{ rs275651 } & Japanese & Takahashi 2000 & 1.44 & $(0.8-2.6)$ & & & 1.23 & $(1.05-1.42)$ \\
\hline & Chinese & Jin 2003 & 1.58 & $(0.99-2.5)$ & 1.77 & $(1.12-2.82)$ & 1.54 & $(1.42-1.68)$ \\
\hline rs275652 & Japanese & Takahashi 2000 & 1.44 & $(0.8-2.6)$ & & & 1.23 & $(1.05-1.42)$ \\
\hline \multirow[t]{8}{*}{ rs1492078 } & African American & Henderson 2004 & 2.56 & $(1.47-4.47)$ & 1.13 & $(0.65-1.96)$ & 1.23 & $(1.21-1.25)$ \\
\hline & $\begin{array}{l}\text { Hispanic } \\
\text { American }\end{array}$ & Henderson 2004 & 0.98 & $(0.75-1.28)$ & 1.31 & $(1-1.71)$ & 1.03 & $(1.01-1.06)$ \\
\hline & German & Zhang 2000 & 0.85 & $(0.62-1.18)$ & 0.54 & $(0.39-0.75)$ & 0.8 & $(0.78-0.82)$ \\
\hline & Japanese & Takahashi 2000 & 1.86 & $(1.14-3.04)$ & 1.27 & $(0.78-2.07)$ & 1.63 & $(1.49-1.79)$ \\
\hline & Chinese Han & Jin 2003 & 1.36 & $(0.92-2.03)$ & 1.42 & $(0.96-2.12)$ & 0.32 & $(1.25-1.4)$ \\
\hline & Tibetan & Sun 2004 & 0.73 & $(0.47-1.15)$ & 0.44 & $(0.28-0.69)$ & 0.74 & $(0.69-0.81)$ \\
\hline & & Summary & \multicolumn{2}{|c|}{ Heterogeneity $P=0.001$} & \multicolumn{2}{|c|}{ Heterogeneity $P=0.08$} & \multicolumn{2}{|c|}{ Heterogeneity $P=0.005$} \\
\hline & & & \multicolumn{2}{|c|}{$I^{2}=76 \%$} & \multicolumn{2}{|c|}{$I^{2}=49 \%$} & \multicolumn{2}{|c|}{$I^{2}=70 \%$} \\
\hline rs422858 & Japanese & Takahashi 2000 & 1.46 & $(0.8-2.65)$ & & & 1.34 & $(1.14-1.58)$ \\
\hline \multirow[t]{2}{*}{ rs275653 } & Japanese & Takahashi 2000 & 1.46 & $(0.8-2.65)$ & & & 1.34 & $(1.14-1.58)$ \\
\hline & Mongolian & Wang 2006 & 0.9 & $(0.63-1.3)$ & 0.93 & $(0.64-1.34)$ & 0.92 & $(0.87-0.97)$ \\
\hline rs5182 & French & $\begin{array}{l}\text { Bonnardeaux } \\
1994\end{array}$ & 1.3 & $(0.82-2.07)$ & 0.99 & $(0.62-1.57)$ & 1.08 & $(1.04-1.11)$ \\
\hline rs5186 & & $\begin{array}{l}\text { See Figures 1, } \\
\text { A-C }\end{array}$ & & & & & & \\
\hline rs380400 & French & $\begin{array}{c}\text { Bonnardeaux } \\
1994\end{array}$ & 0.92 & $(0.61-1.39)$ & 0.57 & $(0.38-0.87)$ & 0.91 & $(0.84-0.97)$ \\
\hline
\end{tabular}

OR, odds ratio; CI, confidence interval. ${ }^{a}$ Heterogeneity $P=0.76$; Egger test $P=0.11$.

${ }^{b}$ Heterogeneity $P=0.69$; Egger test $P=0.14$.

phisms with regard to hypertension or the normal variation of blood pressure. ${ }^{96-98}$ These studies were all underpowered to investigate interaction.

One analysis examined gene-gene interaction between rs275650, rs1492078, and rs5186 with polymorphisms from 11 other candidate genes on hypertension. There was epistasis between the CYP11B2 conversion polymorphism and AGTR1 rs275650 with an OR of 2.10 (95\% CI 1.26-3.51) for A allele homozygotes versus T allele carriers. ${ }^{93}$

\section{Age of onset of hypertension}

Interaction with age of onset of hypertension and rs5186 genotype was examined in one small study, which reported null results. ${ }^{99}$

\section{Diabetes}

Interaction between the AGTR1 rs5186 genotype and diabetes was explored in a stratified analysis of individuals with diabetes versus those with a normal glucose tolerance test. ${ }^{100}$ No associations were noted.

\section{Cholesterol}

One paper investigated the interaction between the AGTR1 rs5186 polymorphism and cholesterol level on the pathogenesis of hypertension. ${ }^{101}$ Given that cholesterol levels varied between groups in much of the literature, this possibility is intriguing. Among those with total cholesterol levels $>220 \mathrm{mg} / \mathrm{dL}$, there was a dramatic increase in the OR from 1.6 (0.9-3.0) to $6.7(1.8-24.7)$. 
Although CIs are wide, and other confounders such as BMI, triglyceride levels, and fasting serum glucose were not accounted for, the evidence for biologic plausibility of this interaction is strong. In vitro studies have shown that low density lipoprotein (LDL) upregulates AGTR1 expression. ${ }^{102}$ Other evidence exists that the vascular response to angiotensin II is modified by LDL levels. ${ }^{103}$

\section{Gender}

As mentioned above, the effect of AGTR1 variants on hypertension risk may vary by gender. In fact, the response to angiotensin II may be altered by gender ${ }^{104}$ via regulation of the AGTR $1 .{ }^{105}$ One article that examined the effect of gender on blood pressure as a continuous variable, did find a numeric increase in systolic and diastolic blood pressures in males but not females with the $\mathrm{C}$ allele. ${ }^{104}$

Odds ratios for hypertension in association with rs5186, stratified by gender, are presented in Table 5 . Under the $\mathrm{AD}$ and additive models, Asian male and female strata demonstrated significant heterogeneity; however, we were able to pool results for the Asian AR models. Results for European populations were nonheterogeneous and summary results are displayed. As illustrated in the figures, results are imprecise, but there is suggestion of an increased risk that is specific to European females.

\section{DISCUSSION}

In summary, the literature regarding the AGTR1 rs5186 polymorphism is heterogeneous, and hence use of an overall summary estimate is inappropriate. Variation among studies with regard to the definition of hypertension and gender composition helps explain the heterogeneity of findings, and the role of these covariates should be explored further. The variability between studies with regard to age, cholesterol levels, and BMI also could explain the heterogeneity of the prevalent literature given their biologic plausibility. Although we didn't find evidence of their influence on heterogeneity, metaregression with this relatively limited number of studies is lacking in power.

Gender-stratified analyses merely suggest that the rs5186 C allele may pose an increased risk for hypertension in Caucasian women, as the presence of publication bias is concerning and the results were not statistically significant. Nonetheless, supportive of our findings is the report of interaction between rs5186 genotype and gender on the renal hemodynamic response to angiotensin II. ${ }^{104}$ Further testing with larger studies or meta-analysis using patient-level data are necessary before forming any definitive conclusions.

We must mention two limitations inherent in conducting numerous subgroup analyses, including 30 homogeneity $\chi^{2} P$-value tests and the estimation of 12 CIs (Table 6). First, the application of the homogeneity $\chi^{2}$ test to many subgroups (and using a $P$-value cutpoint of 0.10 ) will sometimes lead to rejection of the null hypothesis by chance alone, and analysts generally prefer to be conservative in rejecting the null. Here, the null hypothesis is homogeneity, and the alternative hypothesis is heterogeneity. In the context of deciding whether or not to pool study results, the multiple-testing approach should err on the side of being too con- servative (i.e., not pooling results when they should be pooled). Our choice of whether to pool or not was supported by the $\mathrm{I}^{2}$ statistic, which was even more conservative than the homogeneity $P$-value in rejecting pooling. We therefore do not feel multiple testing for homogeneity is problematic. A second, more vexing problem is that two CIs lie above the null value (Table 6), which could have been due to chance. We caution against using the $\mathrm{CI}$ as a test of statistical significance, noting that these subgroups show relatively precise estimates, and precision is a more robust standard of judging estimates than hypothesis testing. ${ }^{106}$ In judging the validity of the subgroup analyses, other considerations must be incorporated (including biological plausibility), and the evidence is weak in this regard.

Another explanation for the inconsistency in results is that binary phenotypes are underpowered. It might be that study of blood pressure as a continuous variable would yield more consistent findings. The few studies conducted thus far, have found no association between rs5186 genotype and blood pressure variation whether studied in population-based cohorts, ${ }^{107-109}$ hypertensives off antihypertensive medication, ${ }^{110-112}$ or nonhypertensive populations. ${ }^{94,95,98,113,114}$

The lack of a functional role of the rs5186 polymorphism makes this SNP somewhat unappealing as a "true" influence of hypertension susceptibility. The available evidence for functionality of AGTR1 polymorphisms is mostly confined to those within the promoter region. Thus far, studies of promoter region polymorphisms have yielded encouraging results especially given many of these SNPs are in LD with one another. Given the dedication of the AGTR1 gene to the promoter region and the role of splicing variants, this region warrants further investigation.

Identification of genetic susceptibilities to hypertension has important public health implications given its high prevalence and large impact on cardiovascular morbidity and mortality. It is premature to conclude any relationship between AGTR1 polymorphic variants and hypertension, and hence there is no role for genetic screening at this time.

The a priori probability for an influential role of the AGTR1 gene on hypertension is quite strong given its biologic relevance. Many physiologic mechanisms contribute to hypertension such as activity of the noradrenergic and RASs, arterial stiffness, and salt sensitivity. It may be that hypertension represents multiple diseases with distinct etiologies. Investigation of these processes as a function of genotypic variation might yield more consistent results, as population stratification could be minimized.

A handful of studies of the rs5186 SNP in association with hypertension-related physiologic mechanisms have been conducted thus far. Studies of the sympathetic postural response $^{114,115}$ and vascular reactivity to alpha-adrenergic stimulation ${ }^{116-118}$ have been conflicting. Similarly, there have been a variety of contradictory findings in the blood pressure ${ }^{109,119-123}$ and renal response ${ }^{109,120,121}$ to angiotensin II. There is no variation in the aldosterone response to angiotensin II with relation to rs5186 or rs188018 genotypes. ${ }^{109,119-121,124}$ Neither salt sensitivity ${ }^{125,126}$ nor renal sodium handling, ${ }^{127}$ seems to vary according to 
rs5186 genotype. Studies of arterial stiffness as indicated by pulse wave velocity ${ }^{110,128}$ or pulse pressure ${ }^{129}$ have been conflicting.

Further study of gene-environment interactions are indicated, particularly with powerful population determinants of hypertension such as obesity and salt intake. Study of single SNPs in isolation is likely to be fruitless given the complexity of the hypertensive phenotype and the need to incorporate multiple variants from multiple genes. Haplotype analysis helps to alleviate some of the burden of genotyping and should likely be the rule for future association studies rather than the exception. Larger studies with a robust definition of hypertension, investigation of processes physiologically relevant to hypertension, appropriate sampling of controls, and consideration of epistasis and gene-environment interaction are necessary to make a true determination of whether AGTR1 polymorphisms have a role in the pathogenesis of hypertension.

\section{References}

1. Laragh J, Pickering TG. Essential hypertension. In: Brenner B, editor. Brenner \& Rector's the kidney. Philadelphia: W.B. Saunders Company, 1991:1913-1967.

2. Gasparo M, Bullock G. The AT1 and AT2 angiotensin receptors. In: Oparil S, Webber M, editors. Hypertension: a companion to Brenner \& Rector's the kidney. Philadelphia: W.B. Saunders Company, 2000:101-110.

3. Brenner B, Cooper M, de Zeeuw D, et al. Effects of losartan on renal and cardiovascular outcomes in patients with type 2 diabetes and nephropathy. $N$ Engl J Med 2001;345:861-869.

4. Lewis EJ, Hunsicker LG, Clarke WR, et al. Renoprotective effect of the angiotensinreceptor antagonist irbesartan in patients with nephropathy due to type 2 diabetes. N Engl J Med 2001;345:851-860.

5. Guo D, Furuta H, Mizukoshi M, Inagami T. The genomic organization of human angiotensin II type 1 receptor. Biochem Biophys Res Commun 1994;200:313-319.

6. Antonellis A, Rogus JJ, Canani LH, et al. A method for developing high-density SNP maps and its application at the type 1 angiotensin II receptor (AGTR1) locus. Genomics 2002;79:326-332.

7. Curnow KM, Pascoe L, White PC. Genetic analysis of the human type-1 angiotensin II receptor. Mol Endocrinol 1992;6:1113-1118.

8. Furuta H, Guo D, Inagami T. Molecular cloning and sequencing of the gene encoding human angiotensin II type 1 receptor. Biochem Biophys Res Commun 1992;183:8-13.

9. Takayanagi R, Ohnaka K, Sakai Y, Ikuyama S, Nawata H. Molecular cloning and characterization of the promoter for the human type-1 angiotensin II receptor gene. Biochem Biophys Res Commun 1994;200:1264-1270.

10. Martin MM, Willardson BM, Burton GF, et al. Human angiotensin II type 1 receptor isorforms encoded by messenger RNA splice variants are functionally distinct. Mol Endocrinol 2001;15:281-293.

11. Su B, Martin MM, Beason KB, Miller PJ, Elton TS. The genomic organization and functional analysis of the promoter for the human angiotensin II type 1 receptor. Biochem Biophys Res Commun 1994;204:1039-1046.

12. Davies E, Bonnardeaux A, Lathrop GM, Corvol P, Clauser E, Soubrier F. Angiotensin II (type-1) receptor locus: CA repeat polymorphism and genetic mapping. Hum Mol Genet 1994;3:838.

13. Liu Y, Qiu C, Zhou W, Zheng Y, Hou S, Cao J. Gene polymorphisms of the reninangiotensin system in essential hypertension. Chin Med J (Engl) 1999;112:115-120.

14. den Dunnen J, Antonarakis S. Mutation nomenclature extensions and suggestions to describe complex mutations: a discussion. Hum Mutat 2000;15:7-12.

15. Zhang X, Erdmann J, Regitz-Zagrosek V, Kurzinger S, Hense HW, Schunkert H. Evaluation of three polymorphisms in the promoter region of the angiotensin II type I receptor gene. J Hypertens 2000;18:267-272.

16. Kee F, Morrison C, Poirier O, et al. Angiotensin II type-I receptor and ACE polymorphisms and risk of myocardial infarction in men and women. Eur J Clin Invest 2000;30:1076-1082.

17. Hindorff LA, Heckbert SR, Tracy R, et al. Angiotensin II type 1 receptor polymorphisms in the cardiovascular health study: relation to blood pressure, ethnicity and cardiovascular events. Am J Hypertens 2002;15:1050-1056.

18. Ermis C, Tsai MY, Hanson NQ, Akar N, Aras O. Angiotensin I converting enzyme, angiotensin II type 1 receptor and angiotensinogen polymorphisms and early myocardial infarction in Turkish population. Thromb Haemost 2002;88:693-694.
19. Olsson M, Annerbrink K, Westberg L, et al. Angiotensin-related genes in patients with panic disorder. Am J Med Genet B Neuropsychiatr Genet 2004;127:81-84.

20. Asselbergs FW, Williams SM, Hebert PR, et al. The gender-specific role of polymorphisms from the fibrinolytic, renin-angiotensin, and bradykinin systems in determining plasma t-PA and PAI-1 levels. Thromb Haemost 2006;96:471-477.

21. Andrikopoulos GK, Tzeis SM, Needham EW, et al. Lack of association between common polymorphisms in genes of the renin-angiotensin system and mortality after myocardial infarction. Cardiology 2005;103:185-188.

22. Buraczynska M, Ksiazek P, Drop A, Zaluska W, Spasiewicz D, Ksiazek A. Genetic polymorphisms of the renin-angiotensin system in end-stage renal disease. Nephrol Dial Transplant 2006;21:979-983.

23. Kato N, Sugiyama T, Morita H, et al. Comprehensive analysis of the renin-angiotensin gene polymorphisms with relation to hypertension in the Japanese. J Hypertens 2000;18:1025-1032.

24. Hirakawa M, Tanaka T, Hashimoto Y, Kuroda M, Takagi T, Nakamura Y. JSNP: a database of common gene variations in the Japanese population. Nucleic Acids Res 2002;30:159-162.

25. Tabara Y, Kohara K, Miki T. Polymorphisms of genes encoding components of the sympathetic nervous system but not the renin-angiotensin system as risk factors for orthostatic hypotension. J Hypertens 2002;20:651-656.

26. Ono K, Mannami T, Baba S, Yasui N, Ogihara T, Iwai N. Lack of association between angiotensin II type 1 receptor gene polymorphism and hypertension in Japanese. Hypertens Res 2003;26:131-134.

27. Sugimoto K, Katsuya T, Ohkubo T, et al. Association between angiotensin II type 1 receptor gene polymorphism and essential hypertension: the Ohasama Study. Hypertens Res 2004;27:551-556.

28. Hindorff LA, Heckbert SR, Tracy R, et al. Angiotensin II type 1 receptor polymorphisms in the cardiovascular health study: relation to blood pressure, ethnicity, and cardiovascular events. Am J Hypertens 2002;15:1050-1056.

29. Hsu CC, Bray MS, Kao WH, Pankow JS, Boerwinkle E, Coresh J. Genetic variation of the renin-angiotensin system and chronic kidney disease progression in black individuals in the atherosclerosis risk in communities study. J Am Soc Nephrol 2006; 17:504-512.

30. Hooper WC, Dowling NF, Wenger NK, Dilley A, Ellingsen D, Evatt BL. Relationship of venous thromboembolism and myocardial infarction with the renin-angiotensin system in African-Americans. Am J Hematol 2002;70:1-8.

31. Ranjith N, Pegoraro RJ, Rom L, Lanning PA, Naidoo DP. Renin-angiotensin system and associated gene polymorphisms in myocardial infarction in young South African Indians. Cardiovasc J S Afr 2004;15:22-26.

32. Jiang Z, Zhao W, Yu F, Xu G. Association of angiotensin II type 1 receptor gene polymorphism with essential hypertension. Chin Med J (Engl) 2001;114:1249-1251.

33. Takami S, Katsuya T, Rakugi H, et al. Angiotensin II type 1 receptor gene polymorphism is associated with increase of left ventricular mass but not with hypertension. Am J Hypertens 1998;11(3 Pt 1):316-321.

34. Jin W, Liu Y, Sheng HH, et al. Single nucleotide polymorphisms in promoter of angiotensin II type 1 receptor gene associated with essential hypertension and coronary heart disease in Chinese population. Acta Pharmacol Sin 2003;24:10831088.

35. Hansen JL, Haunso S, Brann MR, Sheikh SP, Weiner DM. Loss-of-function polymorphic variants of the human angiotensin II type 1 receptor. Mol Pharmacol 2004;65:770-777.

36. Kumar A, Prater A, Li Y, et al. A haplotype of the angiotensin-II receptor subtypeis associated with hypertension in caucasian women. Circulation 2005;11:E52.

37. Pende A, Giacche M, Castigliola L, et al. Characterization of the binding of the RNA-binding protein AUF1 to the human AT(1) receptor mRNA. Biochem Biophys Res Commun 1999;266:609-614.

38. Lehtonen J, Paukku K, Daviet L, et al. Angiotensin II type 1 receptor 1166 polymorphism A to C Increases mRNA stability and steady-state levels. Circulation 2006;114 (18 Suppl. S):190.

39. Abdollahi MR, Lewis RM, Gaunt TR, et al. Quantitated transcript haplotypes (QTH) of AGTR1, reduced abundance of mRNA haplotypes containing 1166C (rs5186:A >C), and relevance to metabolic syndrome traits. Hum Mutat 2007;28: 365-373.

40. Paillard F, Chansel D, Brand E, et al. Genotype-phenotype relationships for the renin-angiotensin-aldosterone system in a normal population. Hypertension 1999; 34:423-429.

41. The international HapMap consortium. The international HapMap project. $\mathrm{Na}$ ture 2003;426:789-796.

42. Zhu X, Yan D, Cooper RS, et al. Linkage disequilibrium and haplotype diversity in the genes of the renin-angiotensin system: findings from the family blood pressure program. Genome Res 2003;13:173-181.

43. Erdmann J, Riedel K, Rohde K, et al. Characterization of polymorphisms in the promoter of the human angiotensin II subtype 1 (AT1) receptor gene. Ann Hum Genet 1999;63(Pt 4):369-374. 
44. Su S, Chen J, Zhao J, et al. Angiotensin II type I receptor gene and myocardial, infarction: tagging SNPs and haplotype based association study. The Beijing atherosclerosis study. Pharmacogenetics 2004;14:673-681.

45. Chobanian AV, Bakris GL, Black HR, et al. The seventh report of the Joint National Committee on prevention, detection, evaluation, and treatment of high blood pressure: the JNC 7 report. JAMA 2003;289:2560-2572.

46. Laragh JH, Brenner BM. Hypertension. Pathophysiology, diagnosis and management, 2nd ed. New York: Raven Press, 1995.

47. Burt V, Whelton P, Roccella EJ, et al. Prevalence of hypertension in the US adult population: results from the third NHANES survey, 1988-1991. Hypertension 1995;25:305-313.

48. Kearney PM, Whelton M, Reynolds K, Muntner P, Whelton PK, He J. Global burden of hypertension: analysis of worldwide data. Lancet 2005;365:217-223.

49. Lawes CM, Vander Hoorn S, Law MR, Elliott P, MacMahon S, Rodgers A. Blood pressure and the global burden of disease 2000. Part 1: estimates of blood pressure levels. J Hypertens 2006;24:413-422.

50. Lewington S, Clarke R, Qizilbash N, Peto R, Collins R, Prospective Studies Collaboration. Age-specific relevance of usual blood pressure mortality: a meta-analysis of individual data for one million adults in 61 prospective studies. Lancet 2002;360: 1903-1913.

51. Lawes CM, Vander Hoorn S, Law MR, Elliott P, MacMahon S, Rodgers A. Blood pressure and the global burden of disease 2000. Part II: estimates of attributable burden. J Hypertens 2006;24:423-430.

52. Wright JJ Jr, Agodoa L, Contreras G, et al. Successful blood pressure control in the African American study of kidney disease and hypertension. Arch Intern Med 2002; 162:1636-1643.

53. Cooper RS, Wolf-Maier K, Luke A, et al. An international comparative study of blood pressure in populations of European vs. African descent. BMCMed 2005;3:2.

54. Hall JE. The kidney, hypertension, and obesity. Hypertension 2003;41(3 Pt 2):625633.

55. Diabetes Prevention Program Research Group. Hypertension, insulin, and proinsulin in participants with impaired glucose tolerance. Hypertension 2002;40:679-686.

56. Nieto FJ, Young TB, Lind BK, et al. Association of sleep-disordered breathing, sleep apnea, and hypertension in a large community-based study. Sleep heart health study. JAMA 2000;283:1829-1836.

57. Wolk R, Shamsuzzaman A, Somers V. Obesity, sleep apnea, and hypertension. Hypertension 2003;42:1067-1074.

58. Caballero A. Endothelial dysfunction in obesity and insulin resistance: a road to diabetes and heart disease. Obes Res 2003;11:1278-1289.

59. Sheetz M, King G. Molecular understanding of hyperglycemia's adverse effects for diabetic complications. JAMA 2002;288:2579-2588.

60. Bragulat E, de la Sierra A. Salt intake, endothelial dysfunction, and salt-sensitive hypertension. J Clin Hypertens (Greenwich) 2002;4:41-46.

61. Midgley JP, Matthew AG, Greenwood CM, Logan AG. Effect of reduced dietary sodium on blood pressure: a meta-analysis of randomized controlled trials. JAMA 1996;275:1590-1597.

62. Stamler J The INTERSALT Study: background, methods, findings, and implications. Am J Clin Nutr 1997;65 (Suppl 2):626S-642S.

63. Pereira MA, Folsom AR, McGovern PG, et al. Physical activity and incident hypertension in black and white adults: the atherosclerosis risk in communities study. Prev Med 1999;28:304-312.

64. Hayashi T, Tsumura K, Suematsu C, Okada K, Fujii S, Endo G. Walking to work and the risk for hypertension in men: the Osaka Health Survey. Ann Intern Med 1999;131:21-26.

65. Beilin LJ, Puddey IB. Alcohol and hypertension: an update. Hypertension 2006;47 1035-1038.

66. Moreira LB, Fuchs FD, Moraes RS, Bredemeier M, Duncan BB. Alcohol intake and blood pressure: the importance of time elapsed since last drink. J Hypertens 1998; 16:175-180.

67. Hunt SC, Hasstedt SJ, Kuida H, Stults BM, Hopkins PN, Williams RR. Genetic heritability and common environmental components of resting and stressed blood pressures, lipids, and body mass index in Utah pedigrees and twins. Am J Epidemiol 1989;129:625-638.

68. Longini IM Jr, Higgins MW, Hinton PC, Moll PP, Keller JB. Environmental and genetic sources of familial aggregation of blood pressure in Tecumseh, Michigan. Am J Epidemiol 1984;120:131-144.

69. Rice T, Vogler GP, Perusse L, Bouchard C, Rao DC. Cardiovascular risk factors in a French Canadian population: resolution of genetic and familial environmental effects on blood pressure using twins, adoptees, and extensive information on environmental correlates. Genet Epidemiol 1989;6:571-588.

70. Snieder H, Harshfield G, Treiber F. Heritability of blood pressure and hemodynamics in African- and European-American youth. Hypertension 2003;41:1196-1201.

71. Cowley AW Jr. The genetic dissection of essential hypertension. Nat Rev Genet 2006;7:829-840.
72. Gong M, Hubner N. Molecular genetics of human hypertension. Clin Sci 2006;110: $315-326$.

73. Liu W, Zhao W, Chase GA. Genome scan meta-analysis for hypertension. Am J Hypertens 2004;17 (12 Pt 1):1100-1106.

74. Koivukoski L, Fisher SA, Kanninen T, et al. Meta-analysis of genome-wide scans for hypertension and blood pressure in Caucasians shows evidence of susceptibility regions on chromosomes 2 and 3. Hum Mol Genet 2004;13:2325-2332.

75. Rice T, Cooper RS, Wu X, et al. Meta-analysis of genome-wide scans for blood pressure in African American and Nigerian samples. The National Heart, Lung, and Blood Institute GeneLink Project. Am J Hypertens 2006;19:270-274.

76. Wu X, Kan D, Province M, et al. An updated meta-analysis of genome scans for hypertension and blood pressure in the NHLBI Family Blood Pressure Program (FBPP). Am J Hypertens 2006;19:122-127.

77. Zintzaras E, Kitsios G, Stefanidis I. Endothelial NO synthase gene polymorphisms and hypertension: a meta-analysis. Hypertension 2006;48:700-710.

78. Sethi AA, Nordestgaard BG, Tybjaerg-Hansen A. Angiotensinogen gene polymorphism, plasma angiotensinogen, and risk of hypertension and ischemic heart disease: a meta-analysis. Arterioscler Thromb Vasc Biol 2003;23:1269-1275.

79. Mondry A, Loh M, Liu P, Zhu AL, Nagel M. Polymorphisms of the insertion / deletion ACE and M235T AGT genes and hypertension: surprising new findings and meta-analysis of data. BMC Nephrol 2005;6:1.

80. Staessen JA, Wang JG, Ginocchio G, et al. The deletion/insertion polymorphism of the angiotensin converting enzyme gene and cardiovascular-renal risk. J Hyperten 1997;15 (12 Pt 2):1579-1592.

81. DerSimonian R, Laird N. Meta-analysis in clinical trials. Control Clin Trials 1986 7:177-188.

82. Greenland S. Meta-analysis. In: Rothman K, Greenland S, editors. Modern epidemiology. Philadelphia: Lippincott Williams and Wilkins, 643-673.

83. Higgins JP, Thompson SG, Deeks JJ, Altman DG. Measuring inconsistency in meta-analyses. BMJ 2003;327:557-560.

84. Deeks JJ, Altman DG, Bradburn MJ. Statistical methods for examining heterogeneity and combining results from several studies in meta-analysis. In: Egger M, Davey Smith G, Altman DG, editors. Systematic reviews in health care: metaanalysis in context. London: BMJ Publishing Group, 2001:285-312.

85. Minelli C, Thompson JR, Abrams KR, Thakkinstian A, Attia J. The choice of a genetic model in the meta-analysis of molecular association studies. Int J Epidemiol 2005;34:1319-1328.

86. Sterne JA, Egger M, Davey Smith G. Investigating and dealing with publication and other biases. In: Egger M, Davey Smith G, Altman DG, editors. Systematic reviews in health care: meta-analysis in context. London: BMJ Publishing Group, 2001 189-208.

87. Davis D, Liyou N, Johnson A. The ACE gene I/D polymorphism, but not the angiotensin II type I receptor gene A1166C polymorphism is associated with isolated systolic hypertension. J Hum Hypertens 2001;15:653-654.

88. Mettimano M, Romano-Spica V, Ianni A, Specchia M, Migneco A, Savi L. AGT and AT1R gene polymorphism in hypertensive heart disease. Int J Clin Pract 2002;56: $574-577$.

89. Miyama N, Hasegawa Y, Suzuki M, et al. Investigation of major genetic polymorphisms in the renin-angiotensin-aldosterone system in subjects with young-onset hypertension selected by a targeted-screening system at university. Clin Exp Hypertens 2007;29:61-67

90. Rolfs A, Weber-Rolfs I, Regitz-Zagrosek V, Kallisch H, Riedel K, Fleck E. Genetic polymorphisms of the angiotensin II type 1 receptor gene. Eur Heart J 1994;15 (Suppl D):108-112.

91. Zhu X, Chang YP, Yan D, et al. Associations between hypertension and genes in the renin-angiotensin system. Hypertension 2003;41:1027-1034.

92. Bonnardeaux A, Davies E, Jeunemaitre X, et al. Angiotensin II type 1 receptor gene polymorphisms in human essential hypertension. Hypertension 1994;24: 63-69.

93. Gu D, Su S, Ge D, et al. Association study with 33 single-nucleotide polymorphisms in 11 candidate genes for hypertension in Chinese. Hypertension 2006;47:11471154.

94. Berge KE, Berg K. Polymorphisms at the angiotensinogen (AGT) and angiotensin II type 1 receptor (AT1R) loci and normal blood pressure. Clin Genet 1998;53:214219.

95. Wang X, Zhu H, Dong Y, Treiber FA, Snieder H. Effects of angiotensinogen and angiotensin II type I receptor genes on blood pressure and left ventricular mass trajectories in multiethnic youth. Twin Res Hum Genet 2006;9:393-402.

96. Dzida G, Sobstyl J, Puzniak A, Golon P, Mosiewicz J, Hanzlik J. Polymorphisms of angiotensin-converting enzyme and angiotensin II receptor type 1 genes in essential hypertension in a Polish population. Med Sci Monit 2001;7:1236-1241.

97. Ashavaid TF, Shalia KK, Nair KG, Dalal JJ. ACE and AT1R gene polymorphism and hypertension in Indian population. J Clin Lab Anal 2000;14:230-237.

98. Henskens LH, Spiering W, Stoffers HE, et al. Effects of ACE I/D and AT1R-A1166C 
polymorphisms on blood pressure in a healthy normotensive primary care population: first results of the hippocates study. J Hypertens 2003;21:81-86.

99. Schmidt S, Beige J, Walla-Friedel M, Michel MC, Sharma AM, Ritz E. A polymorphism in the gene for the angiotensin II type 1 receptor is not associated with hypertension. J Hypertens 1997;15 (12 Pt 1):1385-1388.

100. Lesage S, Velho G, Vionnet N, et al. Genetic studies of the renin-angiotensin system in arterial hypertension associated with non-insulin-dependent diabetes mellitus. J Hypertens 1997;15:601-606.

101. Morisawa T, Kishimoto Y, Kitano M, Kawasaki H, Hasegawa J. Influence of angiotensin II type 1 receptor polymorphism on hypertension in patients with hypercholesterolemia. Clin Chim Acta 2001;304:91-97.

102. Nickenig G, Wassmann S, Bohm M. Regulation of the angiotensin AT1 receptor by hypercholesterolaemia. Diabetes Obes Metab 2000;2:223-228.

103. John S, Delles C, Klingbeil AU, Jacobi J, Schlaich MP, Schmieder RE. Low-density lipoprotein-cholesterol determines vascular responsiveness to angiotensin II in normocholesterolaemic humans. J Hypertens 1999;17(12 Pt 2):1933-1939.

104. Reich H, Duncan JA, Weinstein J, Cattran DC, Scholey JW, Miller JA. Interactions between gender and the angiotensin type 1 receptor gene polymorphism. Kidney Int 2003;63:1443-1449.

105. Nickenig G, Harrison DG. The AT(1)-type angiotensin receptor in oxidative stress and atherogenesis: part II: AT(1) receptor regulation. Circulation 2002;105:530536.

106. Poole C. Low P-values or narrow confidence intervals: which are more durable? Epidemiology 2001;12:291-294.

107. Castellano M, Muiesan ML, Beschi M, et al. Angiotensin II type 1 receptor A/C1166 polymorphism. Relationships with blood pressure and cardiovascular structure. Hypertension 1996;28:1076-1080.

108. Kikuya M, Sugimoto K, Katsuya T, et al. A/C1166 gene polymorphism of the angiotensin II type 1 receptor (AT1) and ambulatory blood pressure: the Ohasama Study. Hypertens Res 2003;26:141-145.

109. Hilgers KF, Langenfeld MR, Schlaich M, Veelken R, Schmieder RE. 1166 A/C polymorphism of the angiotensin II type 1 receptor gene and the response to short-term infusion of angiotensin II. Circulation 1999;100:1394-1399.

110. Lajemi M, Labat C, Gautier S, et al. Angiotensin II type 1 receptor-153A/G and $1166 \mathrm{~A} / \mathrm{C}$ gene polymorphisms and increase in aortic stiffness with age in hypertensive subjects. J Hypertens 2001;19:407-413.

111. Rudnichi A, Safar ME, Lajemi M, Benetos A. Gene polymorphisms of the reninangiotensin system and age-related changes in systolic and diastolic blood pressure in subjects with hypertension. Am J Hypertens 2004;17:321-327.

112. Spiering W, Zwaan IM, Kroon AA, de Leeuw PW. Genetic influences on $24 \mathrm{~h}$ blood pressure profiles in a hypertensive population: role of the angiotensin-converting enzyme insertion/deletion and angiotensin II type 1 receptor A1166C gene polymorphisms. Blood Press Monit 2005;10:135-141.

113. Barbeau P, Kulharya A, Harshfield G, Snieder H, Davis H, Treiber F. Association between angiotensin II type I receptor polymorphism and resting hemodynamics in black and white youth. Ethn Dis 2002;12:S168-71.

114. Nishikino M, Matsunaga T, Yasuda K, et al. Genetic variation in the renin-angiotensin system and autonomic nervous system function in young healthy Japanese subjects. J Clin Endocrinol Metab 2006;91:4676-4681.

115. Stolarz K, Staessen JA, Kawecka-Jaszcz K, et al. Genetic variation in CYP11B2 and AT1R influences heart rate variability conditional on sodium excretion. Hypertension 2004;44:156-162.

116. Henrion D, Amant C, Benessiano J, et al. Angiotensin II type 1 receptor gene polymorphism is associated with an increased vascular reactivity in the human mammary artery in vitro. J Vasc Res 1998;35:356-362.

117. Steeds RP, Toole LO, Channer KS, Morice AH. Human vascular reactivity and polymorphisms of the angiotensin-converting enzyme and the angiotensin type 1 receptor genes. J Vasc Res 1999;36:445-455 discussion 535-8.

118. Amant $\mathrm{C}$, Hamon $\mathrm{M}$, Bauters $\mathrm{C}$, et al. The angiotensin II type 1 receptor gene polymorphism is associated with coronary artery vasoconstriction. J Am Coll Cardiol 1997;29:486-490.

119. Delles C, Erdmann J, Jacobi J, et al. Lack of association between polymorphisms of angiotensin II receptor genes and response to short-term angiotensin II infusion. J Hypertens 2000;18:1573-1578.

120. Miller JA, Thai K, Scholey JW. Angiotensin II type 1 receptor gene polymorphism predicts response to losartan and angiotensin II. Kidney Int 1999;56:2173-2180.

121. Spiering W, Kroon AA, Fuss-Lejeune MM, Daemen MJ, de Leeuw PW. Angiotensin II sensitivity is associated with the angiotensin II type 1 receptor $\mathrm{A}(1166) \mathrm{C}$ polymorphism in essential hypertensives on a high sodium diet. Hypertension 2000; 36:411-416.

122. Vuagnat A, Giacche M, Hopkins PN, et al. Blood pressure response to angiotensin II, low-density lipoprotein cholesterol and polymorphisms of the angiotensin II type 1 receptor gene in hypertensive sibling pairs. J Mol Med 2001;79:175-183.

123. Lim HS, Cho JY, Oh DS, et al. Angiotensin II type 1 receptor $1166 \mathrm{~A} / \mathrm{C}$ polymor- phism in association with blood pressure response to exogenous angiotensin II. Eur J Clin Pharmacol 2007;63:17-26.

124. Kosachunhanun N, Hunt SC, Hopkins PN, et al. Genetic determinants of non modulating hypertension. Hypertension 2003;42:901-908.

125. Giner V, Poch E, Bragulat E, et al. Renin-angiotensin system genetic polymor phisms and salt sensitivity in essential hypertension. Hypertension 2000;35 (1 Pt 2):512-517.

126. Pamies-Andreu E, Ramirez-Lorca R, Garcia-Junco A, et al. Renin-angiotensinaldosterone system and G-protein beta-3 subunit gene polymorhpisms in salt sensitive essential hypertension. J Hum Hypertens 2003;17:187-191.

127. Siani A, Russo P, Paolo Cappuccio F, et al. Combination of renin-angiotensin system polymorphisms is associated with altered renal sodium handling and hypertension. Hypertension 2004;43:598-602.

128. Gardier S, Vincent M, Lantelme P, Rial MO, Bricca G, Milon H. A1166C polymorphism of angiotensin II type 1 receptor, blood pressure and arterial stiffness in hypertension. J Hypertens 2004;22:2135-2142.

129. Mourad JJ, Ducailar G, Rudnicki A, Lajemi M, Mimran A, Safar ME. Age-related increase of pulse pressure and gene polymorphisms in essential hypertension: a preliminary study. J Renin Angiotensin Aldosterone Syst 2002;3:109-115.

130. Sun B, Dronma T, Qin WJ, et al. Polymorphisms of renin-angiotensin system in essential hypertension in Chinese Tibetans. Biomed Environ Sci 2004;17:209-216.

131. Gui-yan W, Yan-Hua W, Qun X, et al. Associations between RAS Gene polymorphisms, environmental factors and hypertension in Mongolian people. Eur J Epidemiol 2006;21:287-292.

132. Poirier O, Georges JL, Ricard S, et al. New polymorphisms of the angiotensin II type 1 receptor gene and their associations with myocardial infarction and blood pressure: the ECTIM study. Etude Cas-Temoin de l'Infarctus du Myocarde. J Hypertens 1998; 16:1443-1447.

133. Takahashi N, Murakami H, Kodama K, et al. Association of a polymorphism at the $5^{\prime}$-region of the angiotensin II type 1 receptor with hypertension. Ann Hum Genet 2000;64 (Pt 3):197-205.

134. Liu KP, Lin CY, Chen HJ, Wei CF, Lee-Chen GJ. Renin-angiotensin system polymorphisms in Taiwanese primary vesicoureteral reflux. Pediatr Nephrol 2004;19: 594-601.

135. Jin W, Liu Y, Sheng HH, et al. Single nucleotide polymorphisms in promoter of angiotensin II type 1 receptor gene associated with essential hypertension and coronary heart disease in Chinese population. Acta Pharmacol Sin 2003;24:10831088.

136. Koh WP, Yuan JM, Van Den Berg D, Lee HP, Yu MC. Polymorphisms in angiotensin II type 1 receptor and angiotensin I-converting enzyme genes and breast cancer risk among Chinese women in Singapore. Carcinogenesis 2005;26:459-464.

137. Kainulainen K, Perola M, Terwilliger J, et al. Evidence for involvement of the type 1 angiotensin II receptor locus in essential hypertension. Hypertension 1999;33: $844-849$.

138. Hashizume K, Mashima Y, Fumayama T, et al. Genetic polymorphisms in the angiotensin II receptor gene and their association with open-angle glaucoma in a Japanese population. Invest Ophthalmol Vis Sci 2005;46:1993-2001.

139. Henderson SO, Haiman CA, Mack W. Multiple polymorphisms in the renin- angiotensin-aldosterone system (ACE, CYP11B2, AGTR1) and their contribution to hypertension in African Americans and Latinos in the multiethnic cohort. Am J Med Sci 2004;328:266-273.

140. Tiret L, Mallet C, Poirier O, et al. Lack of association between polymorphisms of eight candidate genes and idiopathic dilated cardiomyopathy: the CARDIGENE study. J Am Coll Cardiol 2000;35:29-35.

141. Haga H, Yamada R, Ohnishi Y, Nakamura Y, Tanaka T. Gene-based SNP discovery as part of the Japanese millennium genome project: identification of 190,562 genetic variations in the human genome. Single-nucleotide polymorphism. J Hum Genet 2002;47:605-610.

142. Chaves FJ, Corella D, Sorli JV, Marin-Garcia P, Guillen M, Redon J. Polymorphisms of the renin-angiotensin system influence height in normotensive women in a Spanish population. J Clin Endocrinol Metab 2004;89:2301-2305.

143. van Rijn MJ, Schut AF, Aulchenko YS, et al. Heritability of blood pressure traits and the genetic contribution to blood pressure variance explained by four blood-pressure-related genes. J Hypertens 2007;25:565-570.

144. Benetos A, Gautier S, Ricard S, et al. Influence of angiotensin-converting enzyme and angiotensin II type 1 receptor gene polymorphisms on aortic stiffness in normotensive and hypertensive patients. Circulation 1996;94:698-703.

145. Gainer JV, Hunley TE, Kon V, Nadeau JH, Muldowney JA III, Brown NJ. Angiotensin II type I receptor polymorphism in African Americans lower frequency of the C1166 variant. Biochem Mol Biol Int 1997;43:227-231.

146. Tiret L, Blanc H, Ruidavets JB, et al. Gene polymorphisms of the renin-angiotensin system in relation to hypertension and parental history of myocardial infarction and stroke: the PEGASE study. Projet d'Etude des Genes de l'Hypertension Arterielle Severe a moderee Essentielle. J Hypertens 1998;16:37-44. 
147. Liyou N, Davis D, James K, et al. The A1166C mutation in the angiotensin II type I receptor and hypertension in the elderly. Clin Exp Pharmacol Physiol 1999;26: 525-526.

148. Rice GI, Foy CA, Grant PJ. Angiotensin converting enzyme and angiotensin II type 1-receptor gene polymorphisms and risk of ischaemic heart disease. Cardiovasc Res 1999;41:746-753.

149. Nalogowska-Glosnicka K, Lacka BI, Zychma MJ, et al. Angiotensin II type 1 receptor gene A1166C polymorphism is associated with the increased risk of pregnancyinduced hypertension. Med Sci Monit 2000;6:523-529.

150. Canavy I, Henry M, Morange PE, et al. Genetic polymorphisms and coronary artery disease in the south of France. Thromb Haemost 2000;83:212-216.

151. Fatini C, Abbate R, Pepe G, et al. Searching for a better assessment of the individual coronary risk profile. The role of angiotensin-converting enzyme, angiotensin II type 1 receptor and angiotensinogen gene polymorphisms. Eur Heart J 2000;21:633-638.

152. Steeds RP, Wardle A, Smith PD, Martin D, Channer KS, Samani NJ. Analysis of the postulated interaction between the angiotensin II sub-type 1 receptor gene $\mathrm{A} 1166 \mathrm{C}$ polymorphism and the insertion/deletion polymorphism of the angiotensin converting enzyme gene on risk of myocardial infarction. Atherosclerosis 2001;154: $123-128$

153. Coto E, Rodrigo L, Alvarez R, et al. Variation at the angiotensin-converting enzyme and endothelial nitric oxide synthase genes is associated with the risk of esophageal varices among patients with alcoholic cirrhosis. J Cardiovasc Pharmacol 2001;38:833-839.

154. Fernandez-Arcas N, Dieguez-Lucena JL, Munoz-Moran E, et al. Both alleles of the M235T polymorphism of the angiotensinogen gene can be a risk factor for myocardial infarction. Clin Genet 2001;60:52-57.

155. Mettimano M, Lanni A, Migneco A, Specchia ML, Romano-Spica V, Savi L. Angiotensin-related genes involved in essential hypertension: allelic distribution in an Italian population sample. Ital Heart J 2001;2:589-593.

156. Sunder-Plassmann G, Kittler H, Eberle C, et al. Angiotensin converting enzyme DD genotype is associated with hypertensive crisis. Crit Care Med 2002;30:22362241

157. Strazzullo P, Iacone R, Iacoviello L, et al. Genetic variation in the renin-angiotensin system and abdominal adiposity in men: the Olivetti prospective heart study. Ann Intern Med 2003;138:17-23.

158. Jones A, Dhamrait SS, Payne JR, et al. Genetic variants of angiotensin II receptors and cardiovascular risk in hypertension. Hypertension 2003;42:500-506.

159. Luther Y, Bantis C, Ivens K, Fehsel K, Kolb-Bachhofen V, Heering P. Effects of the genetic polymorphisms of the renin-angiotensin system on focal segmental glomerulosclerosis. Kidney Blood Press Res 2003;26:333-337.

160. Papp F, Friedman A, Bereczki C, et al. Renin-angiotensin gene polymorphism in children with uremia and essential hypertension. Pediatr Nephrol 2003;18:150-154.

161. Stankovic A, Zivkovic M, Glisic S, Alavantic D. Angiotensin II type 1 receptor gene polymorphism and essential hypertension in Serbian population. Clin Chim Acta 2003;327:181-185.

162. Bouba I, Makrydimas G, Kalaitzidis R, Lolis DE, Siamopoulos KC, Georgiou I Interaction between the polymorphisms of the renin-angiotensin system in preeclampsia. Eur J Obstet Gynecol Reprod Biol 2003;110:8-11.

163. Kostic M, Stankovic A, Zivkovic M, et al. ACE and AT1 receptor gene polymorphisms and renal scarring in urinary bladder dysfunction. Pediatr Nephrol 2004; 19:853-857.

164. Andrikopoulos GK, Richter DJ, Needham EW, et al. The paradoxical association of common polymorphisms of the renin-angiotensin system genes with risk of myocardial infarction. Eur J Cardiovasc Prev Rehabil 2004;11:477-483.

165. Bellwon J, Sobiczewski W, Gruchala M, et al. An A1166C polymorphism of the angiotensin II AT1 receptor gene does not influence the diagnosis of arterial hypertension during 7 years follow up. Am J Hypertens 2005;18 (5 part 2):100A

166. Tabel Y, Berdeli A, Mir S, Serdaroglu E, Yilmaz E. Effects of genetic polymorphisms of the renin-angiotensin system in children with nephrotic syndrome. J Renin Angiotensin Aldosterone Syst 2005;6:138-144.

167. Sekuri C, Cam FS, Ercan E, et al. Renin-angiotensin system gene polymorphisms and premature coronary heart disease. J Renin Angiotensin Aldosterone Syst 2005; $6: 38-42$.

168. Ece A, Tekes S, Gurkan F, Bilici M, Budak T. Polymorphisms of the angiotensin converting enzyme and angiotensin II type 1 receptor genes and renal scarring in non-uropathic children with recurrent urinary tract infection. Nephrology (Carlton) $2005 ; 10: 377-381$

169. Ozkaya O, Soylemezoglu O, Gonen S, et al. Renin-angiotensin system gene polymorphisms: association with susceptibility to Henoch-Schonlein purpura and renal involvement. Clin Rheumatol 2006;25:861-865.

170. Seremak-Mrozikiewicz A, Dubiel M, Drews K, Breborowicz GH, Mrozikiewicz PM. 1166C mutation of angiotensin II type 1 receptor gene is correlated with umbilical blood flow velocimetry in women with preeclampsia. J Matern Fetal Neonatal Med 2005;17:117-121.
171. Buraczynska M, Ksiazek P, Zaluska W, Spasiewicz D, Nowicka T, Ksiazek A. Angiotensin II type 1 receptor gene polymorphism in end-stage renal disease. Nephron 2002;92:51-55.

172. Nakauchi Y, Suehiro T, Yamamoto M, et al. Significance of angiotensin I-converting enzyme and angiotensin II type 1 receptor gene polymorphisms as risk factors for coronary heart disease. Atherosclerosis 1996;125:161-169.

173. Ishanov A, Okamoto $\mathrm{H}$, Watanabe $\mathrm{M}$, et al. Angiotensin II type 1 receptor gene polymorphisms in patients with cardiac hypertrophy. Jpn Heart J 1998;39:8796.

174. Takemoto Y, Sakatani M, Takami S, et al. Association between angiotensin II receptor gene polymorphism and Serum Angiotensin Converting Enzyme (SACE) activity in patients with sarcoidosis. Thorax 1998;53:459-462.

175. Thomas GN, Young RP, Tomlinson B, Woo KS, Sanderson JE, Critchley JA. Reninangiotensin-aldosterone system gene polymorphisms and hypertension in Hong Kong Chinese. Clin Exp Hypertens 2000;22:87-97.

176. Aoki S, Mukae S, Itoh S, et al. Genetic background in patients with acute myocardial infarction. Jpn Heart J 2001;42:15-28.

177. Liu Y, Zhuoma C, Shan G, et al. A1166C polymorphism of the angiotensin II type 1 receptor gene and essential hypertension in Han, Tibetan and Yi populations. Hypertens Res 2002;25:515-521.

178. Lee KB, Kim UK. Angiotensinogen and angiotensin II type 1 receptor gene polymorphism in patients with autosomal dominant polycystic kidney disease: effect on hypertension and ESRD. Yonsei Med J 2003;44:641-647.

179. Fukazawa R, Sonobe T, Hamamoto K, et al. Possible synergic effect of angiotensin-I converting enzyme gene insertion/deletion polymorphism and angiotensin-II type-1 receptor 1166A/C gene polymorphism on ischemic heart disease in patients with Kawasaki disease. Pediatr Res 2004;56:597-601.

180. Kobashi G, Hata A, Ohta K, et al. A1166C variant of angiotensin II type 1 receptor gene is associated with severe hypertension in pregnancy independently of T235 variant of angiotensinogen gene. J Hum Genet 2004;49:182-186.

181. Yan C, Zhan J, Feng W. Gene polymorphisms of angiotensin II type 1 receptor and angiotensin-converting enzyme in two ethnic groups living in Zhejiang Province, China. J Renin Angiotensin Aldosterone Syst 2005;6:132-137.

182. Nanfang L, Tao L, Ling Z. The study for relationship between the angiotensin II type 1 receptor gene polymorphism and essential hypertension in Kazakans of Xinjiang. J Hypertens 2004;24:240.

183. Kim Y, Kim JH, Nam YJ, et al. Sequence variants of ACE, AGT, AT1R, and PAI-1 as genetic risk factors for vascular dementia. Neurosci Lett 2006;401:276-279.

184. Rehman A, Rasool AH, Naing L, Roshan TM, Rahman AR. Influence of the angiotensin II type I receptor gene 1166A > C polymorphism on BP and aortic pulse wave velocity among Malays. Ann Hum Genet 2007;71 (Pt 1):86-95.

185. Williams SM, Addy JH, Phillips JA III, et al. Combinations of variations in multiple genes are associated with hypertension. Hypertension 2000;36:2-6.

186. Szombathy T, Szalai C, Katalin B, Palicz T, Romics L, Csaszar A. Association of angiotensin II type 1 receptor polymorphism with resistant essential hypertension. Clin Chim Acta 1998;269:91-100

187. Wang W, Zee R, Morris B. Association of angiotensin II type 1 receptor gene polymorphism with essential hypertension. Clin Genet 1997;51:31-34.

188. Romano-Spica V, Mettimano M, Ianni A, Specchia ML, Ricciardi G, Savi L. Epidemiology of essential hypertension: the role of genetic polymorphism. Eur J Epidemiol 2003;18:211-219.

189. Agachan B, Isbir T, Yilmaz H, Akoglu E. Angiotensin converting enzyme I/D, angiotensinogen T174M-M235T and angiotensin II type 1 receptor A1166C gene polymorphisms in Turkish hypertensive patients. Exp Mol Med 2003;35: 545-549.

190. Barbalic M, Skaric-Juric T, Cambien F, et al. Gene polymorphisms of the reninangiotensin system and early development of hypertension. Am J Hypertens 2006; 19:837-842.

191. Behravan J, Naghibi M, Mazloomi MA, et al. Polymorphism of angiotensin II type 1 receptor gene in essential hypertension in Iranian population. DARU 2006;14:82-86.

192. Lapierre AV, Arce ME, Lopez JR, Ciuffo GM. Angiotensin II type 1 receptor A1166C gene polymorphism and essential hypertension in San Luis. Biocell 2006; 30:447-455.

193. Wu K, Lin C, Lin M, et al. The relationships between angiotensin II type 1 recepto gene polymorphism and essential hypertension and its complications (abstract). J Hypertens 2000;18 (Supp 4):S176.

194. Tsai CT, Fallin D, Chiang FT, et al. Angiotensinogen gene haplotype and hypertension: interaction with ACE gene I allele. Hypertension 2003;41:9-15.

195. Wang JG, Staessen JA. Genetic polymorphisms in the renin-angiotensin system: relevance for susceptibility to cardiovascular disease. Eur J Pharmacol 2000;410 289-302. 